Pace University

DigitalCommons@Pace

Pace Law Faculty Publications

School of Law

January 2006

\title{
Paths of Western Law After Justinian
}

M. Stuart Madden

Pace Law School

Follow this and additional works at: https://digitalcommons.pace.edu/lawfaculty

\section{Recommended Citation}

Madden, M. Stuart, "Paths of Western Law After Justinian" (2006). Pace Law Faculty Publications. 130.

https://digitalcommons.pace.edu/lawfaculty/130

This Article is brought to you for free and open access by the School of Law at DigitalCommons@Pace. It has been accepted for inclusion in Pace Law Faculty Publications by an authorized administrator of DigitalCommons@Pace. For more information, please contact dheller2@law.pace.edu. 


\title{
Paths of Western Law After Justinian
}

\author{
M. Stuart Madden ${ }^{\dagger}$
}

\section{INTRODUCTION}

Preparation of the Code of Justinian, one part of a three-part presentation of Roman law published over the three-year period from 533-535 A.D, had not been stymied by the occupation of Rome by the Rugians and the Ostrogoths. In most ways these occupations worked no material hardship on the empire, either militarily or civilly. The occupying Goths and their Roman counterparts developed symbiotic legal and social relationships, and in several instances, the new Germanic rulers sought and received approval of their rule both from the Western Empire, seated in Constantinople, and the Pope. Rugian Odoacer and Ostrogoth Theodoric each, in fact, claimed respect for Roman law, and the latter ruler held the Roman title patricius et magister militum. In sum, the Rugians and the Ostrogoths were content to absorb much of Roman law, and to work only such modifications as were propitious in the light of centuries of Gothic customary law.

By the middle of the sixth century A.D, Justinian I, Emperor of Rome's Eastern Empire, had completed ${ }^{1}$ the three-part Corpus Juris Civilis. The parts themselves, described more fully below, are referred to generally as the Code, the Digests (or Pandects), and the Institutes. To Justinian, this classification, re-codification and modernization of Roman law was part of an overall plan to militarily re-unite the Eastern Empire with the vestiges of the Western Empire, and to have his great legal work regulate the entire Empire. As it would happen, the legacy of Justinian would be the influence of the Corpus Juris Civilis. His military leadership was often ill-advised. He would preside a short period over a unified Empire,

\footnotetext{
${ }^{\dagger}$ Distinguished Professor of Law, Pace University School of Law; Visiting Professor of Law, Santa Clara University School of Law, 2005-06. I would like to thank Santa Clara Research Librarians Mary Hood, Ellen Platt and Amy Wright, for their assistance in imagining and assembling the bibliography for this article.

${ }^{1}$ Naturally, the work itself was that of dozens of scholars and jurists of the day. A fuller discussion of the process and the personages can be found in M. Stuart Madden, 'Graeco-Roman Antecedents of Modern Tort Law' (2006) Brandeis L. Rev.
} 
but upon his death the unified Empire soon fell apart in a condition of social dislocation and poverty, which was worse for Justinian's military efforts. $^{2}$

With military control of Italy, Gaul, Iberia and Northern Africa in continuing ferment, it is understandable that the Roman law of Justinian I was not seamlessly conveyed to its recipients. Indeed, of the whole Corpus Juris Civilis, only the shortest of its three parts, the Code, enjoyed continuous use, if not application, after the fall of the Western Empire towards the end of the sixth century. ${ }^{3}$ After the Western Empire was finally separated from the Eastern Empire, and even in the monarchies in which Roman law would have its most pronounced effect, the integrally important Institutes and the Digests (or Pandects) were lost or simply ignored until their reintroduction in the mid-twelfth century.

Following Justinian, Roman law did not endure as the principal source of law in any nation-state or territory, even on the Italian peninsula. Even before the final Germanic usurpation of the Western Empire, by means of force or assimilation, the Frankish, Ostrogothic and Visigothic populations that had the greatest contact with the Roman Empire, as occupiers or commercial partners, had already blended their own and respective customary law with some of the structure, and some of the substance, of Roman law. This process continued throughout the Early Medieval era. ${ }^{4}$ Following the epoch of Justinian, and upon the establishment of the great Italian university in Bologna and the renewed training of glossators and scholars to study and disseminate Roman Law, scholars and students would return to their countries of origin to teach Roman law. Nevertheless, the legal and political influence of Roman law would never resemble what it might have been had its preservation and

\footnotetext{
${ }^{2}$ Both Justinian's military and short term civil successes were undeniably success. However only 17 years after he reunited Rome, it would fall again.

${ }^{3}$ Munroe Smith, The Development of European Law (Columbia U. 1928), 80.

${ }^{4}$ In England, independently of earlier Roman rule and prior to the later Norman invasion, there had been both a recognized customary law and an early generations of courts empowered to advance it as a distinctly English common law.
} 
dissemination not been so hybridized by its contact with and adaptation to the customary law of the recipient states.

The results of these many marriages between Roman Law and the customary law and culture of the Goths, and the incremental changes in both sources wrought thereby, are identifiable today in the laws of common law nations and civil code nations alike. Three pronounced examples of Germanic law, those of the Lombards, the Burgundians, and the Salian Franks, are the subject of this article.

\section{The FALL OF THE WeStern EMPIRe, The Rugians AND THE OSTROGOTHS}

Before his imperial government could turn its attention to the publication and implementation of the Corpus Juris Civilis, ${ }^{5}$ Emperor Justinian I had first to wrest control of Italy from the Ostrogoths of Theodoric (493-526 A.D.), his Rugian predecessor Odoacer (476-91 A.D.), and also the Franks from Gaul, the Visigoths from Spain, and the Vandals of northern Africa. Justinian's appetites to reunify the Eastern and Western Empires were whetted. He reinvaded Italy in 534 A.D, and after diverse foreign campaigns administered from Constantinople, Justinian proclaimed the reinstitution of Roman rule over Western Empire in August, 554 A.D.

However, the retaking of Italy, together with warfare against the Vandals in northern Africa and the Visigoths in Spain, left the Empire generally enfeebled. Italy itself was probably in a worse condition than it had been

\footnotetext{
${ }^{5}$ The Corpus Juris Civilis comprised three parts. The first part, the Code of Justinian, was intended to be a succinct study manual for lawyers, jurists and students of law. The Institutes of Justinian were the second part, a (if this can be imagined) twenty-volume distillation of literally thousands of volumes interpreting, codifying and analyzing Roman law since the time of the Twelve Tables, a millennium before. The third part was the Digests, or Pandects, which consisted of works of Rome's most celebrated jurists. The Digests did not represent commentary on the compilation of the Code or the Institutes, as some of the works of these jurists preceded the Corpus Juris Civilis by hundreds of years. Yet they represented sources to which the legal and the legislative communities had long turned, and it was Justinian's goal that they continue to be available for this function.
} 
under Odoacer and Theodoric. Justinian's restored rule lasted only fourteen years. He died in 565 A.D, and by 568 A.D. Lombards again occupied large areas of Italy. Within decades their occupation was practically completed. $^{6}$

In broad strokes, the aftermath of the Germanic invasions of Roman territory resulted in the creation of three states or 'empires'. The Ostrogoths ruled northern Italy, the Danubian territories and southeastern Gaul (or modern France). The Visigoths ruled southwestern Gaul and Spain. In these territories much of Visigothic law would merge with Roman law, with consequences that lasted through the later Islamic conquests and that had a pronounced influence on later Spanish law. The third empire was that of the Franks. This encompassed Italy and Spain, as well as, roughly speaking, modern Austria, Germany, Belgium and Holland. $^{7}$

These Germanic intrusions, some peaceable but others not, are attributable to two primary imperatives: (1) the coming, for these groups, of the agricultural age, and the consequent need for arable farmland; or, or coincident with, (2) pressure on these groups by the military advances of invaders from the East, such as the Huns. Unable to turn back the encroachments, the Empire in time adopted such accommodations as it could with the Germanic groups. These agreements gave the newcomers permission to enter the Roman territory in peace, as foerderati, and to secure not only the relative safety they needed but also land for livestock and crops. They gave the Romans what they most needed and were increasingly unable to provide for themselves: security against other threats of invasion by more avaricious and violent tribes.

The Roman landholders were not displaced, but instead adopted a general protocol for sharing their land with their Germanic neighbors. The nuances and operation of these agreements are unimportant for present purposes. One rationale underpinning this arrangement, although not

${ }^{6}$ The Lombard Laws Liber Constitutionum Sive Lex Gundobada; Constitutiones Extravagantes ix (Katherine Fischer Drew, trans; U. Pennsylvania Press, 1973).

${ }^{7}$ Munroe Smith, The Development of European Law xix (Columbia U, 1928). 
necessarily a convincing one, is that this new arrangement of host and guest between the Roman and the Goth was suited to the circumstances of the time, as the Goth might be called upon to join in the defense of the territory, while in his absence the Roman could ensure that the farm would be attended to.

Only for a short period of time, perhaps from 460 to 530 A.D, did all of Italy function as an independent state. Nonetheless, even with the changes in capitals, the crown's relations with the church, and cultural departures from the Pax Romana, the peninsula remained the same state in important ways. ${ }^{8}$ The most conspicuous vestiges of Roman rule would not be swept away in the tenth century.

The Goths comprised Germanic groups who in the earliest of ancient times had settled between the Elbe and the Vistula. They were pagan. In the early Christian era of the Roman Empire, they alternatively invaded or settled in today's Italy, in Gaul, today's France and also parts of northern Italy. As an entirety, they are often described as 'barbarians', which in its colloquial sense means violent, rapacious, and lacking in social refinement. ${ }^{9}$ And it is true that the Germanic tribes of this epoch were in a state of transition from warrior societies to agricultural societies, and that some succeeded in this transition more rapidly than others. But it would be wrong to persist in an image of the Goths as a primitive and unruly lot preternaturally indisposed to cultural and legal advancement. The term 'barbarian', after all, was never a characterization of the behavior of the Germanic tribes, but rather was a simple description that they wore beards, or barbas in Latin. ${ }^{10}$ Also, as the description of their law codes or compilations will reveal, the various Germanic groups were quite politically self-aware. They were deft in their recognition that their rule of the kingdoms within the deteriorating, and then former, Western

${ }^{8}$ Chris Wickhan, Early Medieval Italy: Central Power and Legal Society 400-1000 (Barnes \& Noble, 1981).

9 The second definition of 'barbarian' contained in Webster's Third New International Dictionary (Merriam Webster 1993) is 'marked by a tendency toward brutality, violence or lawlessness...'

${ }^{10} \mathrm{Ibid}$. for definition of 'barbs' or 'barben' as the clipping of wool or the shaving of a beard. 
Empire, required a melding of Gothic customary law with the Roman law of their Roman subjects. This objective was accomplished by two principal means. Some of the Gothic rulers created two parallel statute books, one to be applied to the Germanic tribes and one that would track imperfectly the laws of Justinian and be applicable to the former Roman subjects. A second means was to create a unitary, hybrid body of law that combined a written recitation of Gothic customary law interwoven with precepts, for the most part progressive, of Roman law.

In general, unwritten customary law has always been a retardant to change. In contrast, written codes can be, and often are, modified to conform more closely to cultural expectations. ${ }^{11}$ Thus the very rendering of Gothic customary law into written codes or constitutions was an advancement onto itself, and had resulted from the increased contact of the Germanic tribes with the written legal tradition of the Romans.

After the death of Theodosius in 395 A.D, the Emperor ceased to lead the army. In the fourth and the fifth centuries the civil government, represented by the Senate, was under the constant cloud of and uncertainty concerning the army's commitment to civil rule. There followed Emperors such as Majorian (457-61 A.D.), but the true picture of the Western Empire's condition was measured by the successes of military leaders such as Aetius (429-54 A.D.) and Ricimer (456-72 A.D.). Aetius was assassinated in 454 A.D, but not before continuing the Roman sphere of influence in Gaul, and more importantly, turning back barbarian

${ }^{11}$ In the words of one scholar: '[T] he sanctity and inviobility of tribal custom remained fixed only as long as it was unwritten.' Laws of the Salian and Ripuarian Franks (Theodore John Rivers, transl; AMS 1986), 1. The laws of the Franks are discussed specifically below at $\mathrm{n}$ 149-183 and accompanying text. As to Britain, only in the past century did there become available a fairly full record of the Anglo-Norman study of Roman law. The principal source would be the Liber Pauperum of Vicarius, together with Accursius's Gloss (Glossa Ordinaria). 
invaders of the Empire. ${ }^{12}$ The relationship between Gaul and Italy grew ever more tenuous. ${ }^{13}$

The Western Empire's slide into dissolution was accelerated by the army's revolt over pay, which brought Odoacer to the throne in 476 A.D. He elected to sit at Ravenna rather than Rome. At this period in time the Vandals controlled most of Northern Africa, and even Sicily, although Odaecer succeeded in recovering that island by treaty.

Following Recimer's brief ascension's to the leadership of Italy, serving as patricius, Odoacer instead became King in 476 A.D having declined the Eastern Empire's offer that he become Emperor of the West. There followed fourteen years of relative peace. This peace would end when, without dissent from the Eastern Emperor Zeno, the 489 A.D. invasion of Italy by the Ostrogoths under Theodoric. After four years of war, the Goths took Ravenna and Odoacer was slain in 493 A.D.. ${ }^{14}$ Although Theodoric was a barbarian and an Arian (a sect of Christianity rejected by the Pope), the northern bishoprics thought it prudential to place their support behind Theodoric. The law that might have been available to the Germans in these early years would have been Theodoric's Edictum Theodorici from the year 508 A.D., the Ostrogoth's abbreviated law code intended for his Roman and Gothic subjects alike. The fall of that kingdom in 554 A.D. effectively extinguished the opportunity for Theodoric's code to enjoy any enduring success.

Theodoric's success lay in part in his receiving recognition from the Eastern Empire. His fall followed soon after that recognition was withdrawn in 535 A.D. in anticipation of Justinian's quest to reunify the Empire. However finite in time as was Theodoric's rule, his fall was due

${ }^{12}$ Aetius enlisted mercenary Huns to turn back the Visigoths and Gothic allies. Chris Wickhan, (n 9) 19.

${ }^{13}$ Emperor Avitus (433-6), formerly a Gallic senator and a transparent proponent of an expanded role for Gaul, had his short reign ended after the defeat of part of the Gallic army at the hands of an Italian force under the leadership of Recimir. Chris Wickhan, ibid. at 20 .

${ }_{14}$ Gibbon's The Decline and Fall of the Roman Empire (D..M. Low, abridgement; Chatto and Windus 1960), 531. 
also to his acumen in recognizing the need to maintain support within the Senate, seated in Constantinople, although the Senate was divided between anti-Gothic and pro-Gothic sentiment. The Senate itself continued its slide into ineffectuality, with little legislative activity of consequence, and even major public works projects, such as restoring the Coliseum, were carried out by the Church or by the kings (in the case of the Coliseum, by Theodoric). Much of Italy was devastated by the Gothic wars, and Justinian's triumph would be limited, both in time and in effect. As to the latter, a Brecian landowner, Staviles, is quoted as stating that he 'live[d] the law of the Goths.' 15

What followed was a drama of grand geo-political scope by any measure, past or present. Theodoric was succeeded by his grandson, Althalaric, and his regent, his mother Alalasuntha, was the de facto ruler. Upon Althalaric's death, Amalasuntha married her cousin, Theodahad, who had her killed. At this, the Eastern Empire's Justinian declared war, initiating the Gothic Wars that would last nearly twenty years (535-554 A.D.).

Prior to its hybridization through contact with Roman law, ancient Germanic law was imbued with markedly different themes. With allowances for variations between the different Gothic groupings, Germanic law typically included judicial and quasi-judicial practices that tolerated, or even contemplated, blood feud, with or without the alternative of compensation. This admixture has been described as one that 'intermingle[ed] vengeance, compensation, and kinship liability...,16 Due in substantial measure to the military, cultural and legal changes attending Germanic occupation, it is unsurprising that Justinian's work was not as immediately influential as it might have been if presented and disseminated in a stable Empire. Indeed, these changes and their attendant disruption of traditional Roman legal administration serve in part to explain the practical disappearance of major portions of the Corpus Juris Civilis for several centuries. Only in the late eleventh century and early twelfth centuries would the full texts and interpretations

15 Wickham, (n 8) n 26.

${ }^{16}$ Alexander C. Murray, Germanic Kinship Structure (Pontifical Institute of Medieval Studies 1983), 135. 
(the Pandects and the Institutes) of Justinian be 'found' and reemerge as a basis for civil code scholarship and application. During this interval of up to five centuries, however, the law of the territories within the old Western Empire had not remained in static expectancy of the return of Roman law. Rather, the formerly Western Roman realms, now under Gothic rule, had developed their own bodies of law, relying principally upon tradition, customary law and politic obeisance to Roman law.

As suggested, for a substantial period of time before the fall, or disintegration, of the Western Empire, Rome had in fact relied for its protection and conquest on armies in which a large number of barbarians fought. As to the latter, many Lombards served Justinian in his war with Persia. In their former role, that of protection during the fourth century, Germans integrated into under-populated areas, aided by a practice in which Roman hosts would share land with barbarians. The efforts of the latter would then turn to both agriculture and defense. Germanic pressure for land made this consensual arrangement unstable, and, with the approval of the Romans, the Visigoths eventually settled in Gaul, and later in Spain. After the risks posed by the advances of the Huns from Asia, the Eastern Empire countenanced Ostrogothic settlements in Italy. Further crossings of the Rhine were accomplished by the Vandals, who settled in northern Africa, the Burgundians, who settled in southeastern Gaul, and the Franks, who after setting initially in the northeastern Iberian Peninsula would eventually control all of Gaul. At and during these times the Anglo-Saxons wrested control of Britain from the Romans. ${ }^{17}$

According to one historian, the Western Empire had ceased to exist even before the re-conquests of Justinian, and places the date at approximately 500 A.D. Even before this time, J.M. Roberts writes, the Western Empire could not feed itself without importations from orthern Africa and certain Mediterranean islands. In 476 A.D. Odoacer supplanted the last Western emperor, and Italy became, as the other western territories had or would become, functionally independent, although formally part of an Empire

${ }^{17}$ The Lombard Laws (n 6) 4-5. Justinian was able to reverse some but not all of these depredations, with victory over the Vandals in Africa, the overthrow of the Ostrogoths in Italy, and limited success in Gaul. 
ruled from Constantinople. By 500 A.D, the increasingly unwieldy state apparatus, no longer able to govern efficiently its far flung Empire, had simply 'seized up', or collapsed of its own weight. ${ }^{18}$

Much of primitive law never fully escaped the pull of kinship groups. ${ }^{19}$ It can even be stated that Graeco-Roman law, from the Grecian Code of Solon through and including the laws of Justinian, remained snared in matters of family, because the wrongs of noble families were far fewer than those of ordinary birth, much less those of slaves. Also the remedies the nobility might seek when wronged were characteristically greater than those that might be obtained by those of lower birth. Still and all, the tendency of Graeco-Roman law for harm was an ever-increasing distancing from rules that tied the very definition of the harm as not being solely to the injured party, but rather to the family. The consequence was that the family was both permitted to and expected to vindicate it.

The focus of this article is on the paths of Roman law as it became administered by the new Gothic masters of former Roman territories. To create a context for these subjects, we must first briefly visit the status of Roman law as it was imposed by Justinian I upon the reunification, however short-lived, of the Eastern and the Western Roman Empire. After a final visitation with the body of law prepared at the direction of Justinian I, and to the extent that written recordation makes now it possible, the article will turn to the admixture of Roman and Germanic law enforced by three major Gothic kingdoms: the Burgundians, the Lombards, and the Salacian Franks.

\section{The Limited SURVIVAL Of THE LAW OF JUSTINIAN}

The first part of the Corpus Juris Civilis was intended as a succinct manual for study by lawyers, jurists and students of law, with the twentyvolume Institutes comprising the second part, and as the third part, Digests, or Pandects, contained illuminating legal writings of the

${ }^{18}$ J.M. Roberts, The New History of the World(Oxford 2003) 290, 293.

${ }^{19}$ M. Stuart Madden, 'The Cultural Evolution of Tort Law' (2005) 37 Arizona State L.J. 831 
Empire's preeminent jurists, both past and present. Thus the works in the Pandects did not represent a contemporaneous commentary on the compilations of Justinian. Indeed, some of the work of these jurists preceded the Code and the Institutes by hundreds of years. Yet as the work of revered jurists charged in their own time with interpretation of the evolving Roman law, Justinian identified the Digests as a principal and enduring source to which contemporary jurists and lawyers ought to turn in understanding and interpreting the Code and the Institutes. Together, the Code, the Institutes, and the Digests comprised the Corpus Juris Civilis of 534 A.D.. This compilation, classification and modernization of Roman law are credited with systematizing classic Roman law, ${ }^{20}$ and more importantly, with inventing law as a science. It is in the Corpus Juris that scholars now identify that in Roman law 'the goal of compensation of damage began to prevail over the goal of punishment and sanction. ${ }^{21}$

For this undertaking Justinian employed the assistance of Tribonian, ${ }^{22}$ who thereupon enlisted the help of nine jurists to the task of editing the combined compilations, referenced above, of Gregorian, Hermogenian and Theodosian. Justinian's Code was presented, as had been its predecessor a millennium before, in 12 books or tables. Then Tribonian and seventeen lawyers set about the task of rationalizing, modernizing and extracting from perhaps 2000 treatises, the work of the finest jurists in Roman law. They reduced this body of jurisprudence to approximately fifty books, which would be called the Digests or Pandects.

The Institutes and the Digests of the Jurisconsuls strongly urged a natural law orientation of Roman law. "All peoples who are governed by law and customs use law which is in part particular to themselves, in part common to all men; the law which each people has established for itself is

\footnotetext{
${ }^{20}$ M. Stuart Madden, 'The Graeco-Roman Antecedents of Modern Tort Law' Brandeis L. Rev. Spring 2006 (forthcoming).

${ }^{21}$ Ulrich Magnus, 'Compensation for Personal Injuries in a Comparative Perspective' (2000) 39 Washburn L.J. 348-49.

${ }^{22}$ For reason of his seemingly unsurpassed mastery of the law, culture and science of this era he has been described as the Francis Bacon of his day.
} 
particular to that state and is styled civil law as being particularly of that state: by what natural reason has established among all men is observed equally by all nations and is designated ius gentium or the law of nations, being that which all nations obey. Hence the Roman people observe partly their own particular law, partly that which is common to all peoples. ${ }^{23}$ Evidencing a similarly full-throated natural law commitment to principles of universal duty applicable to all men, the third century jurist Ulpian, quoting Celsus, wrote: 'Justice is a fixed and abiding disposition to give every man his rights. The percepts of the law are as follows: to live honorably, to injure no one, to give to every man his own. Jurisprudence is a knowledge of things human and divine, the science of the just and the unjust. ${ }^{24}$

Here follow several representative examples of delictual liability under the Roman law of Justinian:

Personal Actions, Generally

Committed to the identification of the delineation between "what is "just and what unjust", the Institutes and other sources of Roman law reflect an endeavor to 'give each man his due right', and comprises 'precepts' to all Romans 'to live justly, not to injure another and to render to each his own.' 25 Violation of a 'personal action' not sounding in contract is in delict. $^{26}$

Nuisance and Trespass

\footnotetext{
23 'The Institutes of Justinian, Book 1, Title II' (Concerning Natural Law, the Law of Nations, and the Civil Law) par. 1, in J. C. Smith, David N. Weisstub, The Western Idea of Law (London Butterworths, 1983) 352, from The Institutes of Justinian (J.A.C. Thomas, trans; Juta \& Co. 1975) 3-5.

${ }^{24}$ Ulpian, Digest $1,1,10$, quoted in George Sabine, A History of Political Theory (Holt Rinehart \& Winston 1937), 163-73, in Smith \& Weisstub, (n 24) 349.

${ }^{25}$ The Institutes of Justinian Book I, Preamble; par. 1; par. 3, in Smith \& Weisstub, (n 24) 352, from The Institutes of Justinian (J.A.C. Thomas trans, 1975) 84, 85.

${ }^{26}$ Gaius, The Institutes of Roman Law, Fourth Commentary para 3 in Smith \& Weisstub (n 24) 353, from The Institutes of Roman Law by Gaius (E. Post Trans. 1925) (J.A.C. Thomas trans 1975) 442- 443.
} 
The Institutes include rules that reveal numerous strictures against the imposition of one's will over the rights of a neighbor, and strong deterrents for the disregard thereof. In one notable example, pertaining to what would today be called the law of private nuisance or trespass, a particular provision goes so far as to detail a preference that adjoining landowners bargain in advance for an agreement as to contemporaneous uses of land that might trigger dispute. In Book III par. 4, the Institutes provides that one 'wishing to create' such a right of usage 'should do so by pacts and stipulations. ${ }^{27}$ A testator of land may impose such agreements reached on his heirs, including limitations on building height, obstruction of light, the introduction of a beam into a common wall, the construction of a catch for a cistern, an easement of passage, or a right of way to water. $^{28}$ To much the same effect, and specifically as to urban estates, is Book III, Title II par.2 as interpreted by Gaius in his Institutes of Roman Law, ${ }^{29}$ to which Ulpianus adds a prohibition on the obstruction of a neighbor's view. ${ }^{30}$

\section{Defense of Person and Property}

A man was not free to defend his property with the same degree of freedom as allowed in defending his person. An occupant of property could resist a burglar with non-lethal force. However, in what seems to be an equivalent of a modern (if not universal) rule, a person discovering an invader of his home could not kill him unless he was unable to escape from peril without endangering himself. ${ }^{31}$

\footnotetext{
${ }^{27}$ The Institutes of Gaius continue: 'He can also, by will, charge his heir not to build beyond a given height or not to obstruct the light of the neighbor's premises or to allow the latter to insert a beam into the wall or to accept rain droppings; as also to allow the neighbor a right of passage over his land or to draw water there.' The Institutes of Justinian Book III par. 4, in Smith \& Weisstub, (n 24) 358, from The Institutes of Justinian (J.A.C. Thomas trans 1975) 84, 85 .

${ }^{28} \mathrm{Ibid}$.

${ }^{29}$ Gaius, On the Provincial Edict, Book VII, The Digest (or Pandects) Book VIII Title II par. 2., 359 .

${ }^{30}$ Ulpanius, on Sabinus, BookXXIX, ibid. at Title II par 3, 359.

${ }^{31}$ Dan B. Dobbs, the Law of Torts s 71, pp 161-162, and cases cited therein.
} 


\section{Emotional Distress}

Just as today an emotional distress component in an award for personal physical injury may amplify the compensatory award received by the victim, so too in Roman law the transgressor might be liable to the victim for greater damages when the wrong took place in circumstances that would worsen the harm's same or degradation. Thus, at the penalty phase, a penalty would be made greater if the injuria occurred in a public place. The same aggravation of penalty might accompany a battery in which a man is beaten with sticks, or scourged, or when parents are beaten by their children, or a patron struck by a freedman, or where the injury is to a particularly valuable part of the body, such as the eye. ${ }^{32}$

\section{Theft}

Originally, Roman law treated theft as delictual, or civil, wrong, with accompanying penalties, as referenced below. Only later would theft be catalogued as criminal. Thus for the purposes of the present description, theft can be compared to the various later common law delicts of conversion, trover di bonis asportatis, etc.

Other provisions reflective of the slaveholding era are not of central significance to this treatment. They are nevertheless worthy of mention as an early example of a commitment to favoring the substance of the law over its formal requisites, if such an approach was necessary for the imposition of justice. One delict that occurred with sufficient frequency as to prompt its inclusion in the Institutes was a third party's seduction of another's slave to steal from his master for the benefit of the third party. In order to catch the perpetrator, the law permitted the master to carry out what would today be termed a 'sting' operation, in which the slave would take some goods to the wrongdoer to permit the completion of the wrong. While some jurists were uncertain if the action for theft by stealth (action furti) or action for corruption of a slave (actio servi corrupti) could be

${ }^{32}$ William A. Hunter, Introduction to Roman Law $\left(9^{\text {th }}\right.$ ed.)(F.H. Lawson, rev.)(1955) $140-41$. 
brought, as the owner had consented to the movement of the goods, and the slave had not in fact succumbed to corruption, Justinian disagreed that 'such subtlety' should preclude the bringing of both actions. ${ }^{33}$

Wrongs to Moveable Property

Roman law regarding injury to property was sufficiently supple to recognize variations of injury. The actor could interfere with property by two means: he could deprive the owner of possession by (a) stealth (furtum), or (b) by violence ( $v i$ bona rapta). The wrongdoer might also interfere with the occupier's rights without dispossessing him of the property by damaging the property or otherwise impairing its usefulness (damnum injuria datum). ${ }^{34}$

A man suspecting that his property had been asported to another's house was permitted to search for it, but only upon seeking entry dressed only in a loincloth (licium), and carrying a plate. The origins of the requirement of a loin cloth are thought to predate the separation of the Indo-Germanic, and most probably have a common sense rationale of minimizing the potential that the accuser would contrive to hide goods beneath his clothes and later claim that they had been found in the accused' home. No similar explanation of the requirement of the plate is apparent. ${ }^{35}$

\section{Injuries to Slaves}

Slaves qua slaves had no redress in injuria. Indeed, masters were permitted to flog their own slaves. Conceptually, the slave was not a being in any entire sense, but instead a unit of labor that could lose value if mistreated. However, if another were to injure a master's slaves, the action in injuria was deemed to devolve to the master, as an action in insult, irrespective of whether the actor intended any insult. This would be so even when no severe injury was involved. Should the slave's injury

\footnotetext{
${ }^{33}$ Ibid. 142.

${ }^{34} \mathrm{Ibid}$.

${ }^{35}$ H. F. Jolowicz, Historical introduction to Roman Law, in The Roman Law Reader (F.H.Lawson, ed. 1969) 147.
} 
be severe, the Praetor could grant the master an action in injuria. ${ }^{36}$ The imputation to the master of an injury suffered by a slave has been described as a progenitor to the later law of agency. The reasoning given is that under Roman law the slave had no legal standing. In a juridical sense he was absorbed into his master's family and represented before the law by his master. In later eras of freed men or freed servants, it would be a substantial but measured step to visualize the free servant as enjoying a relation to his master (employer) similar to that of the ancient slave to his master. The final step in this analysis is the identification of circumstances, be they broad or narrow, in which the actions of the servant are treated in a legal sense as the actions of the master. ${ }^{37}$ If a wrongful injury was inflicted upon a child (persons under potestas), the remedy in injuria would lay in the father (paterfamilias), who could bring an action both on his behalf and on behalf of his child. ${ }^{38}$ From what it appears, this approach partakes at least in half measure of that taken for injuries to slaves, with the damage to the father being essentially in insult and/or lost services.

Following the fall of the Western Empire, the full three parts of the Corpus Juris Civilis simply disappeared from usage. Where accessible at all, only the Institutes and partial versions of the Code were available for study in the Middle Ages. Only in the first parts of the twelfth century would the resource in a largely integral form regain prominence, and this through the fortuitous discovery of a sixth century manuscript of the Digest, examined at Amalfi and then at Pisa and Florence. It became the basis for the study of Roman law at Bologna, arguably the leading new center for political and legal study. ${ }^{39}$

\footnotetext{
${ }^{36}$ Hunter, ibid. 141.

${ }^{37}$ In Holmes' words: 'This is the progress of ideas as shown us by history; and this is what is meant by saying that the characteristic feature which justifies agency as a title of the law is the absorption pro hac vice of the agent's legal individuality in that of his principal.' Oliver Wendell Holmes, The Common Law (1880).

${ }^{38} \mathrm{Ibid}$.

${ }^{39}$ Frances de Zulueta, Peter Stein, The Teaching of Roman Law in England Around 1200 (Selden Society 2000), 1.
} 


\section{The Burgundian Code (LeX Gondobada)}

Prior to the hybridization of Germanic law occasioned by its contact with Roman law, blood feud had enjoyed centuries of observance among Gothic groups. In the customary law of Germanic tribes the victim's kinship group was permitted to wreak retribution upon the slayer himself or his family. This remedy that might today seem unruly at best was simply a norm that was considered just and not unduly disruptive of the community. The movement towards a wergeld ${ }^{40}$ approach could naturally be seen as consistent with new Germanic kingdoms within contained domains, and with the stronger central authority predictably appurtenant thereto. ${ }^{41}$ The stronger the central authority, the logic continues, the more likely it is that the monarch and his constituents will come to consider pursuit of justice through blood feud to be a disturbance of the king's peace. This concept would later underlie the doctrines of public nuisance and trespass vi et armis. For society, now settled for the first time into stable agricultural and economic matrices, resolution of murder or manslaughter through blood feud would logically become increasingly unpopular. The rules for compensation, whether tied to lost life or to any other catalogued wrongdoing, were quantified in soladi, the value of which was measured in grains of gold. ${ }^{42}$ Both before and after

\footnotetext{
${ }^{40}$ Wergeld represented the value of a person's life, reduced to a money amount. The composition for an innocent or negligent homicide, or often even an intentional homicide, was the payment of the wergeld to the victim's family. Each of the Gothic codes examined here adopted a form of wergeld or wergild.

${ }^{41}$ What the slave did was unaccounted for in the calculation of wergeld, the early unwritten forms of Germanic customary law or the later hybridized and written versions. Munroe Smith, (n 7) 12: 'The slave ... is a thing, not a person. In the earliest Germanic law he is constantly compared to an animal. If he is killed, no wergeld is paid to his master, but damages based on value, as in the case of animals. The master has the power of life and death over the slave. The slave acquires not for himself but for his master.' To Smith's account I would only add that in cases of liability for what a slave has done, the approach was one of two: either the master would be required to pay composition for the slave's acts, or the slave, who would have no money, would be physically punished. See e.g., notes and accompanying text.

${ }^{42}$ In the time of Constantine, a solidus was worth about 120 grains of gold. The Burgundian Code: Liber Constitutionum Sive Lex Gundobada; Constitutiones Extravagantes (Katherine Fischer, transl; U. Pennsylvania Press 1949), 19 n 4.
} 
the widespread adoption of compensatory resolutions for conflicts, responsibility or innocence in relation to a wrong would be determined by oath taking. Fact witnesses had no opportunity to testify for or against a party. The claimant and the accused were both given an opportunity to state the basis for their claim or defense to the magistrate. Upon so doing, the respective parties would bring before the court oath takers. Under the Burgundian Code the requisite number was 12 , and they could include relatives. What was sought from the oath takers was not an attestation as to what had occurred, but rather an affirmation as to the integrity and the honesty of the person on whose behalf they appeared. ${ }^{43}$

In or about 406 A.D., the approximate time of the Vandal invasion of Roman territory around the Rhine, the Burgundians too took arms against what is now northern Germany. There they ruled from 413 to 436 A.D, when they were overrun by the Huns. But as would happen in many instances of Roman cooption of former enemies, by 443 A.D. the Romans had granted the Burgundians certain territory in Savoy between Lake Geneva the Rhone and the Alps. ${ }^{44}$ This Roman grant was in return for the Burgundians' assistance in safeguarding the Western Empire against Germanic and other groups deemed to be a greater risk to the Empire.

Provision of land to the Burgundians followed the logic and practice of hospitalitas between host and guest as mentioned above. This approach was generally also taken with other Germanic populations, including the Lombards. Land was allotted pursuant to a rule of 'hospitality', and provided that the land within the affected territory would be parceled out in a ratio of two thirds to the Burgundian 'guests' (hospes), and one-third to the Roman 'host' (also hospes). The Roman host would in turn keep two-thirds of the slaves, with one-third going to the Burgundian guest.

\footnotetext{
${ }^{43}$ In contrapuntal distinction to the Burgundian approach, western law would come to reject the relatives of the opposing party as being in any way acceptable on a jury. Even as witnesses, relatives will have their objectivity assailed, and of course testimony as to the general good reputation of a defendant is only permitted after the claimant has placed it in issue. See also ibid. (explaining with specificity the procedures for oath taking).

${ }^{44}$ E. A. Thompson, Romans and Barbarians: The Decline of the Western Empire 23-24 (Wisconsin 1982).
} 
The rationale of this arrangement, albeit not necessarily convincing, was that it resolved three principal objectives of the Empire. First, the arrangement slaked, for the time, the Burgundian's thirst for new agricultural land. Second, it brought, and literally bought, a peaceable cessation of combat with the Burgundians. Third, insofar as the new role of the Burgundians was to aid Rome in the protection of the Western Empire, they could be expected to be called to arms periodically. In their absence, with the Roman host still in situ, the farms and livestock would not go unattended. This arrangement of hospitality with the Burgundians would typify accords that were similar, in both form and function, of Rome's relation with other Germanic groups. ${ }^{45}$

To the increasingly powerful Franks, the Burgundian land seemed a delectable prize, and they sought it by force of arms. The Salian Franks attacked the Burgundians in 500 A.D, but were unable to prevail. Not long thereafter, and since the concept of allies and enemies in these times was very fluid, the Salian Franks and the Burgundians joined forces to defeat the Visigoths in 507 A.D. ${ }^{46}$

Now custodians of land that had for centuries been ruled under Roman law, the Burgundians under King Gundobad, who ruled from 474 A.D. to 516 A. D. ${ }^{47}$ apparently thought it politic not to force feed Burgundian customary law to its Roman citizens. Instead the Burgundians sought to merge their own customary law with Roman law in a way that would not prove unpalatable to either population. The books containing law applicable to Burgundians in affairs inter se, or in matters between

${ }^{45}$ It bears mentioning that Rome had by this time centuries of experience in the assimilation of persons of other nations. In 212 A.D. it had granted citizenship 'to all free subjects of the empire.' J.M. Roberts, The New History of the World 250 (Oxford 2003).

${ }^{46}$ An excellent resource as to the Visigoths and their social structures is P.D. King, Law and Society in the Visigothic Kingdom (Cambridge 1972).

${ }^{47}$ These are the dates ordinarily assigned, although other scholars have differed, e.g., E. A. Thompson, Roman and Barbarians: The Decline of the Westem Empire 24 (Wisconsin 1982), in which the author puts the dates at c. $480-516$ A.D. The point here is not so much whether a particular royal reign was a few years longer or shorter, but rather that many of the dates contained in such histories are not entirely certain. 
Burgundians and Romans, had various names, in large part due to conflicting translations: Lex Burgundionum; Liber Legum Gundobadi; Lex Gundobada, la Loi Gombette, and Gombata. The laws applicable to Romans in their dealings with other Romans were collected in the book Lex Romana Burgundionum. These separate constitutions (or codes) were subject over time to numerous revisions during the reign of Gundobad, but it is estimated that in the aggregate they were compiled between 488 and 533 A.D. This approach was consistent with an ever widening practice among Germanic kingdoms to adopt two sets of law: one a simulacrum of the customary law of the new rulers, for application to the invaders, and the other, drawing from Roman law sources, for application to Romans within the territory. As to the former, it has been claimed that the laws published under Gundobad's reign relied in many ways on the Lex Visigothorum, published in 483 A.D. under Visigoth King Euric. ${ }^{48}$

The description to follow of the Burgundian Codes will reveal numerous similarities with the Roman law of the lands they were now to rule. This can be seen as an astute effort to harmonize the legal and cultural differences between two very distinct peoples. Like other Germanic codes, the Burgundian Code provided that Roman citizens would be judged by Roman law and that ignorance of the law was no defense. ${ }^{49} \mathrm{~A}$ principal Gothic contribution to the Lex Gundobada was its continuation of the Germanic customary law concept of wergeld ${ }^{50}$ By adopting this approach to resolution of disputes over intentional or innocent murder, payment of wergeld was in lieu of other and violent forms of response by the victim's kinship, in forms such as blood feud. This is not to say that the Burgundians were definitionaly averse to the penalty of a life for a life. Section 1 of the Law of Gundobad provided for the ultimate penalty in cases of intentional murder. ${ }^{51}$

\footnotetext{
${ }^{48}$ The Burgundian Code, supra note 6 at 4-5, 7 .

${ }^{49}$ Lex Gundobada (First Constitution) s I para 8. Book of Constitutions para 8.

${ }^{50}$ For an explanation of wergeld or wergild, see note 41.

51 'If anyone presumes with boldness or rashness bent on injury to kill a native freeman, ... let him make restitution for the committed crime not otherwise than by the shedding of his own blood.' Lex Gundobada (First Constitution) s II para 1.
} 
In more general terms, the king's objective in setting forth the Burgundian Code was twofold. First, the objectives of the realm sound in the very reasoning that even today underlie a state's assertion of its police power as to matters affecting the health, safety and welfare of citizens. Second, the Code is intended to provide uniform rules of general applicability for administration by counts (comites) and the magistrates (praeepositi) who will be called upon to render judgment. ${ }^{52}$

\section{Negligence and Accidental Harm}

The Burgundian Code assigned a different and lower level of culpability to harm caused by accident or negligence and that caused purposeful. In an example of an injury arguably inflicted by one man upon another, the Burgundian Code states that a purely accidental injury imports no liability. The Code uses the example of man with a lance. If a lance has been thrown on the ground, or left there 'without intent to do harm' (simpliciter), and 'if by accident a man or an animal impales himself thereon', the injury is considered a simple accident and no legal consequences follow. The provision distinguishes a setting in which at the time of the injury the lance is being held by the man 'in such a manner that it could cause harm to a man. ${ }^{53}$ While the provision does not explicitly so state, there are two reasonable implications of the distinction drawn: (1) the man who is holding the lance at the time of the injury may have a higher level of culpability than does the man who is not in control of the lance when the injury occurs; i.e., he may be seen as being careless,

\footnotetext{
${ }^{52}$ In keeping with the Burgundian inattentiveness to the organization that characterized Justinian's Code, this language is found in a section pertaining to damage caused by animals:
}

This is established for the welfare and peace of all, that a general definition be set forth relevant to each and every case, so that the counts and magistrates of the localities, having been adequately instructed, may understand how matters should be judged.

Lex Gundobada (First Constitution) s XLIX para 1.

${ }^{53}$ Lex Gundobada (First Constitution) s XVIII par. 2. 
rendering the mishap not attributable to pure accident; and (2) this distinction suggests that there may be some remedy in composition for the man's holding the lance in what would be described today as a negligent manner.

Regarding animals, the Code expressly disposes of its 'ancient rule of blame'. With its specific references to animals, the provision rejects strict liability for injuries caused by one's animals. Lex Gundobada Section XVIII par. 1 provides that if a horse accidentally kills another horse, or an ox an ox, or a dog a dog, no money damages will be required. The matter will be settled by having the owner of the animal that attacked the other simply hand the animal over to the owner of the injured animal. Even for the more serious loss of a dog's bite killing a man, no composition at all was required, 'because what happens by chance ought not to conduce to the loss or discomfiture of man. ${ }^{, 54}$

\section{Theft or Conversion Regarding Chattels}

Compensation for other delicts, such as trover, would be provided for by replacement in kind of the animal or object stolen. For example, one stealing the little bell (tintinnum), and presumably the horse itself, would be required to 'return another horse like it; and let like provision be observed concerning a lead ox. ${ }^{55}$ Similar to today's distinction between trespass to chattels and conversion, ${ }^{56}$ the Lex Gundobada differentiated between significant disruption of ownership rights and lesser ones that might be characterized as mere intermeddling. If a freeman rode off on another's horse, but returned it within a day, he would be required to pay two soladi to the owner. If the interloper kept the horse for more than one day, he would be subject to the more stringent penalties governing the wrongful use of another's horse on journey. ${ }^{57}$

\footnotetext{
54 Lex Gundobada (First Constitution) s VIII para 1, titled 'Of Those Things That Happen By Chance.'

${ }^{55}$ Lex Gundobada (First Constitution) s IV para 3.

${ }^{56}$ E.g., Compuserve v Cyber Promotions, 962 F Supp 1015 (SD Ohio 1997).

${ }^{57} \mathrm{See}$ discussion below at notes.
} 
In some sections, the Lex Gundobada might ordain composition with a type of property different from that involved in the theft. For example, a freeman's theft of another's plowshare would warrant composition of 'two oxen with yoke and attachments (harness) ... ${ }^{58}$ This declaration of a remedy in seeming disproportion to the value of the personality most probably reflects an agricultural community's strong antipathy towards theft of items so central to its means of livelihood.

Separate provision was made for the more serious crime of theft by violence. In a rule applicable to Burgundians and Romans alike, the Code provided that one who by violence took away from its possessor 'anything, even a young calf,' would be fined the value of the item or animal 'ninefold'. This clearly introduces an extra-compensatory provision that bears similarities to today's punitive damages. The ninefold penalty is nine times that which would be required for the purposes of compensatory justice. Full $8 / 9$ of the award is intended to punish the perpetrator. Those throughout the community who learn of such a judgment are certain to consider it a deterrent from pursuing the same or similar conduct. While modest multiples of value was employed frequently throughout the several Gothic codes, a multiple of nine was preserved to serve the different purpose of imposing a more severe extra compensatory penalty and of conveying a stronger deterrence message to the community.

When an attempted theft was associated with a trespass, the rights inuring to the landholder enlarged substantially. The importance of vineyards to societies in this time is evident in the uncompromising response the Burgundian Code took towards thieves who entered a vineyard by night. The owner could kill him without incurring liability. ${ }^{59}$ Should the thieves' trespass for the purpose of theft occur during the day, the matter could be remedied by the payment of three soladi to the owner and two soladi to the crown. ${ }^{60}$

\footnotetext{
${ }^{58}$ Lex Gundobada (First Constitution) s XXII para 9.

${ }^{59}$ Lex Gundobada (First Constitution) s CIII para 2.

${ }^{60}$ Lex Gundobada (First Constitution) s CIII para 1.
} 
Over centuries and across continents, severe punishment has attended a crime either resulting from a conspiracy or even the conspiracy itself. This was also so in the Lex Gondobada. For example, should a 'native freeman and a slave commit a theft together', the freeman was required to pay three times the value of what was stolen, and the slave would be flogged. If, however, it was a 'minor theft', e.g. 'a pig, a sheep, a goat, or a hive of bees', he would be liable in composition for six soladi. Bearing in mind the distinction between the operative words 'together' and 'with', a different rule applied to the freeman who committed a theft merely accompanied by (or 'with') his slave. The freeman would be liable in composition for an amount 'threefold' the value of what was stolen, and, it almost goes without saying, the slave would be flogged. ${ }^{61}$

In a most extraordinary provision, the Lex Gondobada states that a person who steals a hound or a hunting or running dog must 'kiss the posterior of that dog in the presence (in conventu) of all the people'. Alternatively, and we can well imagine that most persons elected this alternative, he would pay five soladi to the owner and a fine of two soladi to the state. ${ }^{62}$

\section{Disturbing the Peace; Battery and Wounds}

All violence was thought to disturb the peace. Even if no blow was inflicted, one a person drawing a sword 'for striking another' would be fined twelve soladi by the crown. If a blow were to fall, the fine to the king would be the same, and the amount of composition to the victim would depend on the severity of the wound. ${ }^{63}$

In matters of battery, the magistrate as fact finder was required only to decide whose version of the events was to be believed, and then had to apply those facts to a schedule of penalties. Thus a person found liable for wounding another would be held responsible in composition depending on the nature of the injury.

\footnotetext{
${ }^{61}$ Lex Gundobada (First Constitution) s XCI para 1.

${ }^{62}$ Lex Gundobada (First Constitution) s XCVII para 1.

${ }^{63}$ Lex Gundobada (First Constitution) s XXXCII para 1.
} 
For example, one who struck a freeman would be liable for a single solidus for each blow, plus an additional fine of six solidi to the king's treasury. ${ }^{64}$ A person who cut off the arm of a freeman or a slave would be liable for half of the victim's wergeld. A wound of any lesser severity would be 'judged according to the nature of his wound." ${ }^{65}$ A wound to the face was dealt with more severely. The penalty was three times the amount that would be due for an injury to a '[body] part which is protected by clothing., 66

The wrongful breaking of bones received special attention. The Burgundian Code stated that if one broke another's arm, or his shinbone, but the person regains the use of it, composition would be set at $1 / 10$ of the victim's wergeld. If in contrast the victim were to suffer 'a clear disability,' the composition would be set according to the magistrate's evaluation of the extent of the injury. ${ }^{67}$ The knocking out of teeth also garnered separate treatment, with composition set according to the class of the victim. The assailant imprudent enough to knock out the teeth of a 'Burgundian of the highest class' or a Roman noble was required to pay fifteen soladi. ${ }^{68}$

\section{Homicide}

As to the defense against a charge of homicide, provisions were made for justifiable homicide. For instance, where a man is 'injured by blows or wounds', 'pursues his persecutor' and slays the initial attacker while yet in a state of 'grief and indignation', his potential liability for intentional murder will be tempered by evidence of his mental state (only, of course, if supported by oath takers). Upon such proof, and if the fatal injury was

\footnotetext{
${ }^{64}$ Lex Gundobada (First Constitution) s V para 1.

${ }^{65}$ Lex Gundobada (First Constitution) s XI para 1. Of course the slave, as chattel of his master, would not receive the damages, be it in wergeld or otherwise.

${ }^{66}$ Lex Gundobada (First Constitution) s XI para 2.

${ }^{67}$ Lex Gundobada (First Constitution) s XLVIII paras 1, 2, 3, 4.

${ }^{68}$ Lex Gundobada (First Constitution) s XXVI para 1. The composition set for the injured member of the middle class was ten soladi, and for "persons of the lowest classes' it was five soladi.
} 
that sustained by a man of the middle class (mediocris), the matter could be resolved by payment of 100 soladi. ${ }^{69}$ While such a quasi-excuse for justifiable homicide might at first be seen as an implicit acquiescence in violent retribution for homicide, it must be reiterated that a substantial monetary penalty potentially awaits the initial victim who pursues and kills his assailant. Thus, there remained a significant financial disincentive to engage in self-help and to leave justice to the magistrates. Moreover, the Lex Gundobada is quick in its effort to deter the victim's family from starting a blood feud with the family of the killer, stating that 'the relatives of the man killed must recognize that no one can be pursued except the killer ..., ${ }^{70}$ A provision of this type is an exemplar of Germanic codes' move away from kinship-based remedies of revenge and self-help towards systems of rectificatory justice. ${ }^{71}$

Departures from this tendency would appear to have involved homicide in the course of robbery of a merchant or another. The perpetrator could be sentenced to death. If the goods or moneys stolen could not be located, the victim would be compensated 'in fee simple' from the wrongdoer's property. $^{72}$

\section{Self-defense}

Under the Burgundian Code the privilege of defending oneself was not a complete defense, but rather only a partial one. ${ }^{73}$ More precisely, if a

\footnotetext{
${ }^{69}$ Lex Gundobada (First Constitution) s II para 2. As might be expected, the composition payable was higher if the victim was a nobleman (optimas nobilis), and smaller if he was from the lowest class (minor persona). Ibid.

${ }^{70}$ Lex Gundobada (First Constitution) s XI para 1 (emphasis added).

${ }^{71}$ Slaves did not enjoy the benefits of this progressive sensibility, as capital penalties continued to exist for certain delicts of slaves. For example, a slave who was solicited to steal a horse, mare, ox or cow could be 'handed over to death ...' Lex Gundobada (First Constitution) s IV para 1.

${ }^{72}$ Lex Gundobada (First Constitution) Sect. XXIX par. 1

${ }^{73}$ Regarding only the limited privilege of self-defense with deadly force, see People $v$ Wilner, 879 P 2 d 19 (Colo. 1994), following rule permitting defense with deadly force where such defense is reasonable in response to the threat. Dobbs (n 32) 162.
} 
man defends himself by using violence against his assailant, even if any 'acts of this sort [are] from necessity', he remains liable for 'half the established payment according to the degree of blame. ${ }^{74}$ For example, if a man defending himself were to knock out the teeth of a member of the middle class, which would ordinarily require a payment of ten soladi, ${ }^{75}$ he would remain liable in composition for half of that amount. Obviously, the rule differs from the modern one that permits a person to take reasonable measures to defend himself, although the privilege ceases when the assailant no longer poses a threat, i.e., when he has been subdued or has fled. It is quite possible that even though the provision's applicability is limited to defensive acts 'from necessity', the realm concluded that there would be additional value in the minimization of injury if the man defending himself operated under a norm that protected him from half, but not all, liability, to wit. The Code can be interpreted as a response to a concern that having the privilege of self-defense operated as a complete defense, the law would not deter the victim from responding more violently, or for a longer period of time, than was necessary.

\section{Trespass to Home and Land}

The Burgundians placed great value on the sanctity of their homes, and the king, in turn, considered violent entry into a home an intolerable disruption of the public peace. This is evidenced in the section of the Lex Gundobada governing a person's entry into another's home for the purposes of starting a fight. In a provision applicable to Romans and Burgundians alike, the perpetrator would pay six soladi to the owner of the home and another twelve soladi to the king's treasury.

As with Justinian's Code before and all notable civil code and common law provisions that would follow, redress was provided for trespass to

\footnotetext{
${ }_{74}^{74}$ Lex Gundobada (First Constitution) s XLVIII para 4.

${ }^{75}$ Lex Gundobada (First Constitution). If the assailant who lost his teeth was a member 'of the lowest classes', the gross composition set at five soladi (Lex Gundobada (First Constitution)) and the man defending himself would remain responsible for half of that amount etc.
} 
land without the need to show actual harm. Indeed, under the Lex Gundobada, this was a matter of private composition and of payment to the crown, signifying the awareness within the realm that quasi-criminal fines were an appropriate means for emphasizing the seriousness of such defalcations. A trespass to land that involved breaking into the close obliged the wrongdoer to pay three soladi to the owner and a fine of six soladi to the king. ${ }^{76}$ If breaking a fence was for the purpose of providing pasture for an intruder's horses, he would pay one solidus for every animal as composition for the damage to the crops or meadow. ${ }^{77}$

Entry to another's vineyard by day could entail payment of 'three soladi for his presumption[,]' while the landowner's encountering a trespasser entering by night into 'a vineyard bearing fruit' could kill him in defense of his vineyard (and its grapes), with no composition due to the trespasser's family or master. ${ }^{78}$ A communitarian approach was taken with regard to Burgundians and Romans who did not possess forest and trees. They would be permitted to enter another's forest and to take the wood of fallen trees without penalty. But if the entrant cut down fruit bearing, pine or fir trees in another's forest, he would be obliged to pay the owner one solidus for each such tree. ${ }^{79}$

If a Burgundian or a Roman planted a vineyard on another's land by mistake, which is to say, without the objection of others, he would be required to satisfy the true owner with a 'like field ...' If, however, a man after 'prohibition' (notice) persisted in doing so, he would be required to cede the improved property to the true owner and could recover nothing for his labor. ${ }^{80}$

Damage by Fire

\footnotetext{
${ }^{76}$ Lex Gundobada (First Constitution) s XXV para 1. The provision speaks in terms of one who 'enters a garden with violence,' but the implication is not one of violence against man or animal, but rather the pushing aside or the breaking of a fence or a gate to enclosed land, as distinct from trespassory entrance into another's open field (discussed at notes and accompanying text).

${ }^{77}$ Lex Gundobada (First Constitution) s XXVII para 4.

${ }^{78}$ Lex Gundobada (First Constitution) s XXVII para 8.

${ }^{79}$ Lex Gundobada (First Constitution) s XXVIII para 2.

${ }^{80}$ Lex Gundobada (First Constitution) s XXXI paras 1, 2.
} 
The Burgundian Code treats in extenso the liability that follows damage caused by a fire transmitted either accidentally to, or set deliberately on another's property. A person who set a fire in a clearing, which subsequently traveled to another's land unaided by wind, was required to make composition by replacing anything burned. ${ }^{81}$ It is possible that the application here of a composition standard of replacement in kind, rather than in liquidated or value-based damages in soladi reflects considerations of administrative cost and judicial competence, as well as pragmatic necessity. First, it is fairly straightforward to assign a liquidated value in soladi in composition, with or without an additional fine to be paid to the king's treasure, for injury to or even theft of a more or less fungible chattel, such as a plowshare, a horse or an ox. Once the universe of property that can be damaged or destroyed is enlarged to include damage by fire to, for example, the contents of a house, and the almost limitless categories of personalty that might be contained therein, an accounting in money damages for the items would be both difficult and inherently unreliable. Second, in terms of pragmatic necessity and the limited number of vendors accessible to them, it may have been better though to place the burden of acquisition and replacement on the wrongdoer.

\section{Injuries Caused by or Trespass of Animals}

Generally, the Lex Gondobada, like other Germanic codes, followed a rule of strict liability for damages caused by a horse or other agricultural animal. $^{82}$ These types of incidents are to be distinguished from the common law rules regarding, for example, innocent trespass onto adjoining land by animals being herded on a public way. In a departure from strict liability for the acts of animals, if a pig should damage a vineyard or a tilled field, and if the owner had been warned twice of this, the owner of the damaged property was entitled 'to kill the best from the

\footnotetext{
${ }^{81}$ Lex Gundobada (First Constitution) s XLI para 1.

82 For statements of similar rules of law in Great Britain and in the United States, see Tillett $v$ Ward, L.R. 10, Q.B.D. 17 (1882); Wood v Snider, 79 NE 858 (N.Y. 1907).
} 
herd and turn it to his own use. ${ }^{83}$ A like provision is found in the later Lex Gondobada (Constitutioines Extragantes XVIII par. 1), for pigs found in another's vineyard. A potential rationale for having an explicitly self-help remedy for foraging pigs but not for farm animals such as horses or oxen is that among these animals only the pig is a comestible.

If a man penned animals that had entered his property and had caused damage, the owner seeking to recover them was required to pay a trimissis for each animal and a fine of three soladi. In a humane vein, one section regarding the protection of wandering horses declares a predicate observation that horses wandering at large have sometimes been subjected to mistreatment. The Code provides that any such horse found must be turned over to the king where, pending establishment of ownership, 'they may be guarded with zeal and diligence'. ${ }^{84}$ Concerning all animals that are wont to wander off, one was not permitted to seize a horse 'wandering at large through the countryside.' If, on the other hand any such animal was found to be doing damage to property, the property owner could pen up the animal, and bring 'suit' (in this context, give notice) of the whereabouts of the animal. If the owner did not arrive within two days, the possessor was permitted on the third day, and 'in the presence of witnesses', to drive the animals off. ${ }^{85}$ Should the original owner come forward, another section of the Code provides for only partial composition regarding damages caused by animals, ${ }^{86}$ a remedy, it can be seen, that falls short of reestablishment of the status quo ante.

There is another provision limited to partial composition of an owner's remedy for damage caused by animals. Let us say that one settler's (vicini) animals are causing damage to their enclosure, and for this reason another man drives the animals to enclosures on his own property. If, thereafter, if the animals are killed by 'mischance (i.e., without fault) ... before he can send a messenger and bring immediate notice to their

\footnotetext{
${ }^{83}$ Lex Gundobada (First Constitution) s XXIII para 4.

${ }^{84}$ Lex Gundobada (First Constitution) s XLIX para 4.

${ }^{85}$ Lex Gundobada (First Constitution) s XLIX para 4.

${ }^{86}$ See also the rule relating to self defense. See Lex Gundobada (First Constitution) Sect. par.
} 
owner,' the man last in possession of the animals is responsible in composition for only half of the animals' value. ${ }^{87}$

It would seem sensible that a man should be permitted, without incurring liability, to drive another's animals from his land, without the predicate of notice, etc., even if the animal was injured in the course of being driven. Indeed, the Lex Gundobada so provided. ${ }^{88}$ If any animals are driven justifiably into the enclosure of another, if the man doing this fails to give notice to the true owner that he must retrieve them and any mishap causes death to the animals, the possessor would be liable for their entire value. If, conversely, the possessor did give notice and the true owner fails to regain possession, and the animals are killed, the possessor would not be liable. $^{89}$

Both the visible and the potential for different outcomes under these several rules is most likely due to the fact that the Lex Gundobada, as was characteristic of all Gothic codes, was the subject of ongoing revision by appointees of the realm. Such revisions were often not accompanied by careful scrutiny for conflicts.

Injuries to Animals

A man killing a dog 'without apparent cause' was required to make composition of one solidus. ${ }^{90}$ If an animal, presumably a beast of burden or a horse, should be killed in the course of a harvest, the man responsible would be liable for 'the value of the animal'. 91

Perhaps the term 'horseplay' derives from the sometimes cruel pranks that adults and children alike have worked upon horses. If a man clipped

${ }^{87}$ Lex Gundobada (First Constitution) s XLIX para 1.

${ }^{88}$ Lex Gundobada (First Constitution) s XXIII para 2.

${ }^{89}$ Lex Gundobada (First Constitution) s XLIX para 2.

${ }^{90}$ Lex Gundobada (First Constitution) s LVIII para 1.

${ }^{91}$ Lex Gundobada (First Constitution) s LXIV paras 1, 2. 
the tail of another man's horse, he would be responsible for turning over to the owner a horse of the same value. ${ }^{92}$

\section{Dignitary harms}

The Burgundians do not seem to have treated with any breadth what might be described as the conventional dignitary torts, such as defamation. One provision nonetheless addresses the effrontery of cutting a woman's hair 'in her courtyard'. The perpetrator would be liable for thirty soladi in composition to the woman and fined twelve soladi to the benefit of the king's treasury. ${ }^{93}$

\section{Hospitality}

In more primitive times, travel entailed substantial risks, both from the elements and also from persons of ill will. As a consequence of this, the Burgundian Code recognized duties of hospitality to travelers to provide the 'roof and hearth'. A Burgundian refusing this to a traveler would be required to pay to the traveler three soladi 'for the neglect.' If the denial of hospitality were less overt, such as a Burgundian directing the traveler to the house of a Roman, the Burgundian would be liable to both the Roman and the traveler in the amount of three soladi. ${ }^{94}$

\section{False Imprisonment}

Provision was made for at least a subset of the acts that today would be named false imprisonment. If a freeman bound against his will an innocent freeman, he would be required to pay twelve soladi to the one bound and a fine of twelve soladi to the crown. The Lex Gundobada followed a continuum of examples in which native inhabitants were favored over immigrants or visitors. The rule for false imprisonment represents one such example. For binding a nonnative freeman, the composition would be six soladi, with the same amount payable to the

\footnotetext{
${ }^{92}$ Lex Gundobada (First Constitution) s LXXIII para 3.

${ }^{93}$ Lex Gundobada (First Constitution) s XCII para 1.

${ }^{94}$ Lex Gundobada (First Constitution) s XXIX para 7.
} 
king's treasury, ${ }^{95}$ a varied treatment that probably reveals nothing more than a political tropism towards the rights of established Burgundians and Romans more vigorously that the protections afforded an immigrant, even if a freeman.

\section{Perjury and False Oaths}

The authors of the Code were sagacious in their understanding of human vulnerability to manipulation of facts in any setting in which they might consider it to be in their enlightened self-interest so to do. The Burgundian Code introduces the sections on perjury and false oaths with language that could be mistaken for both legislative findings of fact and a statutory statement of purpose, and states: "We know that many of our people are corrupted through inability to establish a case and because of instinct of greed, so that they do not hesitate frequently to offer oaths about uncertain matters and likewise perjure themselves about known matters.' To deter these practices the Lex Gundobada outlines the potential outcomes when a claim is brought: (1) if a claim is brought and supported by oaths, and it is found that the accused committed the wrong, the matter is resolved in favor of the claimant; (2) if the accused is confronted with a claim that is supported by oath takers, but declines to receive the oaths, he is free to demand trial by combat, but the combat on behalf of the accused is to be made by an oath taker who supported the accused, letting 'God be the judge.' If the accuser's proxy is killed, the remaining oath takers must pay the man originally accused the sum of 300 soladi. If, though, the accused is killed, the accuser shall be paid ninefold the value of the harm initially alleged. '[A]s a result' of this means, the section concludes, 'one may delight in truth rather than in falsehood. ${ }^{, 96}$

\section{Dangerous Instrumentalities}

One section of the Burgundian Code addresses the then contemporary means of trapping wolves and imposes specific precautionary duties upon

\footnotetext{
${ }^{95}$ Lex Gundobada (First Constitution) s XXXII paras 1, 2.

${ }^{96}$ Lex Gundobada (First Constitution) s XLV para 1.
} 
those who would use them. One trap consisted of a bow so arranged that if triggered, the animal (a wolf, for example) would be killed by an arrow. Naturally, such a trap also created a risk of killing people or domestic animals. The trapper was therefore required to strategically place two additional triggers so that a man or animal would encounter them before entering the true zone of danger. These additional triggers would similarly loose arrows, but they were designed to strike harmlessly. Should a person be killed, a trapper who took the prescribed precautions would be liable in composition only for the comparatively modest sum of twenty-five soladi. In contrast, if the trapper did not so safeguard his traps and a man was killed inconsequence, he would be obligated to pay in composition the entire wergeld of the deceased. ${ }^{97}$ More generally regarding, a different rule applied for one who set 'a trap for wild animals outside of cultivated land'. If he did so in a 'deserted spot', and a man or an animal was injured thereby, 'no blame shall be attributed to him who owned the trap'. 98

\section{Deceit and False Witness}

All customary law and early law codes contained provisions regarding deceit or false witness, but not all treated perjury. The Laws of King Liutprand did so, and provides that 'If any freeman advises another freeman to perjure himself[,]' he is liable to pay 100 soladi 'for that illegal advice which he offered contrary to reason. ${ }^{, 99}$

\section{THE LAW OF THE LOMBARDS (ROTHAIR's EDICTS)}

With the Lombards in Italy, as was true of all Germanic occupation of Roman territory, realpolitik obligated the Germanic kings to recognize that they were the minority population in a largely Roman land. Upon assumption of the administration of Roman territory, the barbarian kings recognized that they were required to play 'a dual role. ${ }^{, 100}$

\footnotetext{
${ }^{97}$ Lex Gundobada (First Constitution) s XLVI paras 1, 2, 4.

${ }^{98}$ Lex Gundobada (First Constitution) s LXXII para 1.

${ }^{99}$ Laws of King Liutprand 72.III.

${ }^{100}$ The Lombard Laws supra note 6 at 11.
} 
The ends of the Ostrogothic and the Western Empires that provided the cultural and political window for the new Lombard state. ${ }^{101}$ To what is now northern Italy, the Lombards brought peace and a helpful lack of antagonism towards the papacy. Rothair's 643 A.D. Edictum was written in Latin and were composed within the context of a society in its transition from pre-literacy to literacy. The Lombards did not destroy the Western Empire. Indeed, the Law Codes of Rothair and those that followed were written in Latin. They made discriminating use of Justinian's Code, and Lombard leaders enlisted Roman lawyers to advise Lombard judges.

While not so deferential to Roman culture, law and the church as had been the Ostrogoths, increased Lombard trade with western territories yet under Roman rule led by the Seventh Century to an 'orientalization' of parts of Italy. The introduction of Greek and Syrian clergy was especially noteworthy, as were the reciprocal visits of Byzantine Emperor Constantine to Italy in 663 A.D. and the Pope to Constantinople in 710 A.D. The Lombards gradually turned from Arianism to Christianity.

From the Fifth to the Seventh Centuries, the sources of post-Justinian law as they persisted in the Italian peninsula are limited, but include both local charters and edicts of greater territorial scope from Naples, Verona, Milan and other smaller municipalities. From the Seventh Century onwards, the record is fuller. As would be expected, the laws of Rothair revealed a marked move away from rules incorporating kinship considerations. Those provisions that did reference kinship were limited to legal questions in which family or family of origin might sensibly bear. For example, reference is made to extended family groups (farae) in the rules relating to migration within the kingdom. Lineage (parentilla) was a proper consideration in matters of inheritance, and a confined kinship group (parentes) was denied for purposes of oath helping and feud. Rothair's Edict is apparently otherwise oblivious to kinship. ${ }^{102}$

\footnotetext{
${ }^{101}$ Nevertheless, some sixty years would pass between the end of the Ostrogothic kingdom and the ascension of the Lombards. The Lombard Laws ibid. xvi.

${ }^{102}$ Wickham (n 8) 116-17.
} 
As with other Germanic groups, in earlier times of the Lombards, resolution of serious wrongs might be 'resolved' by blood feud (faeda). This corporal and even lethal answer to grievances, which might be wrought against the offending individual, his family, or both, was characteristic of ancient eras in which it fell to the family or the kinship group to obtain justice. By the time of Theodoric, the state's influence was sufficiently strong, and its structure for provision of remedies of an apparently just nature had become sufficiently accepted, that resort to blood feud became increasingly rare. Trial by combat, referenced below, is to be distinguished, .

While increasingly less prevalent under the Lombards, resolution of selective disputes by feud did persist. This can be explained by several factors. The threshold observation is that feud was a social institution that was very ingrained in Germanic custom. Thus, neither the people nor their leaders were likely to consider feuds a material threat to the public peace, much less to the state. Also, most feuds did not last for very long, and various means for nonviolent resolution with honor were interwoven within the custom itself.

Lombard law made no distinction between criminal and civil delicts. As a consequence, actions were not brought by the state for criminal penalties, incarceration or physical punishment. Modern scholarship suggests several potential explanations for this are insightful, at least as they apply before medieval times. James Lundgren points to (1) the private law remedies available to early peoples, which were often quite strict and even brutal; (2) the great likelihood of detection in early and smaller societies without the help of the government; and (3) the adoption by many of these groups of liquidated amounts that might be paid in composition for the loss of a life (a full wergeld) or for lesser injuries. ${ }^{103}$

103 James Lundgren, "Why the Ancient Systems May Not have Needed a System of Criminal Law' (1996) 76 Boston U. L. Rev. 29, 31-32; Richard A. Posner, 'An Economic Analysis of Criminal Law' (1985) 85 Columbia L. Rev. 1193, 1203-04, in which the author writes: 
Taken together, Lundgren suggests, these private law approaches obviate the need for state enforcement in the form of criminal law and penalties, such as incarceration.

Institutional capacity is probably the final piece to the puzzle. The Romans had not only the authority to identify and separate private wrongs from public ones, but also the resources to support both quasi-judicial and penal confinement systems. The unprecedented capacity of the Romans (at least in the Western world) to create a bright line between civil and criminal wrongs was reflected the nature and power of their governance. It would not be an approach that would either appeal to, or be feasible for, societies with less structure, fewer resources, or both. Even so, conviction for many wrongs in the time of the Lombards might result in what today would be termed quasi-criminal penalties, with the court imposing a fine, half of which would escheat to the state and the other half to the injured party.

Importantly, because such judgments, with the exception of a judgment for a full wergeld for a death, were ordinarily in the form of fines, and payable only in the proportion of perhaps one-half to the victim or his family, the quasi-criminal nature of these remedies for delict would frequently fell short of compensating the injured parties for the true extent of the harm. Still, the opportunity to receive substantial if incomplete pecuniary redress for a delict, as determined before an impartial

Primitive and ancient societies (including Anglo-Saxon England) have relied more heavily than has our society on a form of tort damages (usually fixed in amount rather than assessed individually in each case) - 'bloodwealth,' 'wergeld,' 'composition,' - to control crime, apparently with some success. Among other things that makes this approach feasible are lack of personal privacy, which makes probabilities of apprehension and conviction high, and the principle of collective responsibility, which makes the offender's kinship group liable for his damages, thus enabling the society to set fines that exceed the individual's ability to pay.

Richard A. Posner, 'An Economic Analysis of Criminal Law' (1985) 85 Columbia L. Rev. 1193, 1203-04. 
magistrate, represented an advancement in certainty over the prior practices of blood feud.

The Lombard Laws were codified and published in a succession beginning with the most influential of them that of Rothair the seventeenth king of the Lombards. As noted, Rothair's Edict was published in 643 A.D. ${ }^{104}$ The Laws of King Grimwald would follow in 668 A.D., ${ }^{105}$ with the Laws of King Liutprand being published in 724 A.D. ${ }^{106}$ The Laws of King Grimwald contained no provisions germane to tort-like wrongs, but those of King Liutprand did, while often incorporating by reference Rothair's Edict.

In general it can be stated that what Lombard Law lacked in systemization, it made up for in particularity. Nowhere in Lombard Law is the legal taxonomy of provisions into categories such as 'wrongs to persons' or 'wrongs to property', categorizations that Justinian's Code, for example, would leave as an enduring legacy in western law. Yet at least as it pertained to liability for delicts both Rothair's Edict and the Laws of King Liutprand, and particularly Rothair's Edict, were not surpassed in its seeming devotion to recording a comprehensive recitation of the sprawling array of wrongs for which remedies might be sought.

Under Rothair's Edictum, to gain redress for a wrong, the aggrieved must bring an action for damages. Similar to the approach taken by other nonLatins, the Lombards employed two means of judicial proof: compurgation and trial by combat. Resort to the latter, trial by combat, was infrequent. Trial by compurgation relied not upon evidence presented by witnesses, but rather upon the party's reputation. 'Oathtakers' (sacrementales), whose numbers might be as many as twelve, and who might include relatives, would take an oath vouching for the integrity of the party. This collective oath would be taken into

${ }^{104}$ The leading translation of these several codifications is found in The Lombard Laws (Katherine Fischer Drew, trans.)(U. Pennsylvania 1973), and the provisions of Rothair's Edict contained therein will cited hereinafter to the edict itself.

${ }^{105}$ The Lombard Laws ibid. 131.

${ }^{106}$ Ibid. 137. 
account by the magistrate in determining if the party's account of events was truthful. ${ }^{107}$

In overview, for a wrong resulting in another's death, the Lombards adopted the common Germanic concept of wergeld, with the value of the deceased's life to be paid to the victim's family. ${ }^{108}$ For personal injury not resulting in death, the penalty would vary depending upon the seriousness of the injury or incapacitation. For harms to property, compurgation might be in the form of the property lost or damaged, e.g., crops or animals, or in coin. The Lombard Laws also took into account instances in which the physical harm might be slight but the dignitary harm great. ${ }^{109}$

\section{Public Nuisance}

One of the original and most important objectives of law has been the maintenance of order. While threats to order can arise in an almost limitless number of ways, the most classic among them has been breach of the public peace (scandulum). Rothair's Edict adopted a gender-based treatment for redress of any injuries sustained in a public brawl. If a woman was to participate in a brawl in which men were involved and she is injured or killed, composition would be due to her or her family as though the injury had been sustained by a man in her family. With apparent reference to an actual decision rendered by the court, however, Rothair's Edict No. 378 continues by explaining that even though the gravity of the harm might warrant a payment of 900 soladi, ${ }^{110}$ the woman should recover nothing, as 'she had participated in a struggle in a manner dishonorable for women.'

\section{Assault and Battery}

\footnotetext{
${ }^{107}$ Ibid. $26-27$.

${ }^{108} \mathrm{Ibid}$. 27. See also explanation of wergeld and wergild at note 41 above.

${ }^{109}$ E.g., Rothair's Edict, discussed below.

${ }^{110}$ The value of a solidus, or its multiple in soladi, is described above at note 42 and accompanying text, as used by the Burgundians. I do not here compare the value differentiation as might have occurred between and among the Burgundians, the Lombards and the Salacian Franks.
} 
The penalty for the injurious striking of another would vary depending upon the loss sustained. Rothair's Edict No. 377 governed the blinding of a man with only one good eye, and set the composition at two-thirds of the amount that would be due if the man had been slain. ${ }^{111}$ Laws of King Liutprand No. 124.VIII states that a man who by striking a slave left him or her crippled must pay the master one half the composition that would be due had the slave been slain.

\section{Unintentional Homicide}

For homicide generally, be it unintentional or intentional, Code of King Liutprand describes the means of calculation of the appropriate composition for another's life. This measurement is to be made 'according to the quality of the person', a concept that is consistent with the calculation of wergild as used throughout this discussion. It was nonetheless seemingly decided that the process would profit from some higher degree of predictability, and Laws of King Liutprand 62.VIIII give it just that. It states that it should be recognized as 'custom' that 'a lesser person (minima persona) who is a freeman (excercitalis) shall have a wergild of 150 soladi, and he who is of the first class (primus) shall have a wergild of 300 soladi.

For cases of unintentional homicide, Rothair's Edict proposes composition and discourages blood feud. Composition for the death is pursuant to wergild, which is to say, 'the price at which the dead man is valued.' And, the Edict concludes with language encouraging composition over feud, and reads: 'feud shall not be required since it was done unintentionally. 112 It is obvious that the composition in the amount of wergild adopted throughout Germanic law represents a lineal juridical predecessor to the wrongful death statutes that would follow, many of which are in force today.

\footnotetext{
${ }^{111}$ If the same injury should be sustained by a one-eyed slave, the composition to be paid would be as though the slave had been slain. Ibid. The logic of this is probably found in the fact that it might be considered that there was no value in a sightless slave.

${ }^{112}$ Rothair's Edict No. 387.
} 
As with all Germanic groups adopting agricultural societies, the clearing of land and the felling of trees was an essential part of the endeavor. It is inevitable that many injuries, even deaths, would result. Rothair's Edict No. 138 pertains to the unintended (happening 'without design') killing of a man by a tree cut down by several men. It provided: 'If two or more men cut down a tree, and another man coming along is killed by that tree, then those who were cutting the tree, however many they were, shall pay composition equally for the composition or for the damage.' Thus whatever sum might be assigned as wergild for the life of the victim, Edict No. 138 states that the perpetrators shall share equally in the payment of the total, an early example of comparative responsibility. Should one of the tree cutters be accidentally killed, Edict No. 139 provided, by way of example, that 'if there were two colleagues, half the wergild would be assessed to the dead man and the other half shall be paid to the relatives [of the dead man].' Should more than two cutters be involved, liability would be assigned congruently, with 'an equal portion . .. assessed to the dead man and to those who still live', with each paying an equal share of the wergild. By this means of composition in resolution of the accident, Edict No. 138 concludes, the risk of feud is extinguished.

\section{Intentional Homicide}

The Laws of King Liutprand set forth dire penalties for the unexcused slaying of another, with the penalties to be exacted not only upon the perpetrator but also upon his heirs. The party responsible must turn over all of his property to the family of the victim. If the value of the property exceeds that value which would be assigned as composition for the lost life, then the victim's family keeps the proportion as is of a value equivalent to an appropriate wergild, and any excess goes half to the king's treasury and half to the victim's family. If, on the other hand, the value of the property were less than that which would be a fair composition, the assailant would lose all of his property and is turned over himself to the "nearest relatives of the dead man."113 While the laws

${ }^{113}$ Laws of King Liutprand No. 20.II. It may be presumed that the man turned over to the victim's family may be treated as a chattel slave. The section ends curiously with 
do not elaborate, it may be intimated that the family would be free to exact revenge on the assailant once he had been turned over.

Self Defense

If one killed a 'mad man' in self-defense, Rothair's Edict No. 323 dispensed with liability, although it required that 'he not be slain without cause.' King Liutprand developed the defense more broadly to state that a freeman killing another in self-defense should be liable in composition for the lost life of the other, but should otherwise be punished. ${ }^{114}$

\section{Negligence}

As was earlier shown in the Lex Gundobada, ${ }^{115}$ the several Gothic groups were practiced in assigning social expectations of care, and in imposing liability upon those whose duties of care were breached. Rothair's Edict No. 148 provided: 'He who makes a fire beside the road should extinguish it before he goes away and not leave it negligently.' Any damage cause by such a fire would require composition only in the amount of the value of what was damaged, as the act was not done intentionally. Potential liability for harm caused by such a fire would be limited to harm occurring within twenty-four hours after the fire was abandoned. Potential liability would also be extinguished should any damage be caused after the fire crossed an open road or a stream. ${ }^{116}$

language following that providing that if the value of the perpetrator's land exceeds that sufficient to award composition, half goes to the victim's family and half escheats to the king. It states that 'in this way the man who committed the homicide may redeem his life.' Yet according to the earlier language even if the assailant's property exceeds wergild for the victim's life, the perpetrator keeps nothing. This leaves if unclear how or with what the wrongdoer may redeem his life.

${ }^{114}$ Laws of King Liutprand No. 20.II.

${ }^{115}$ See discussion above at Burgundian Code, 'Negligence and Accidental Harm'.

116 This provision illuminates early concepts of duty, liability for negligence, proximate cause, and pure compensatory damages. The duty of reasonable care is defined by the statement that a man should extinguish a fire before leaving it. The limitation of liability, should the fire cross an open road or a stream, is consistent with modern concepts of proximate cause. Lastly, the composition owed for accidental harm is set at the actual value of the damaged property. 
Trespass to Land and Interference With Boundary Markers

Numerous provisions of Rothair's Edict and also the Laws of King Liutprand address matters that would today sound in trespass to land. Under Rothair's Edict, if a man, even by innocent mistake, plows another man's field, or seeds it, he has no recourse for any improvement or harvest from the land against the true owner. ${ }^{117}$ If he plows over another's seeded field he must return any fruits he destroyed and also "pay six soladi as composition for his heedless presumption." 118 The Laws of King Liutprand provide that one who digs a ditch on another's land must pay to the rightful owner six soladi, ${ }^{119}$ and that one putting a fence on another's land must pay the same amount. ${ }^{120}$

As sensible to any rules governing and agricultural society, a sequence of provisions addresses interference with the boundary markers of another's land. The penalty was quasi-criminal, for such interference was considered, an effrontery not only to offended property owner but also to the king. Rothair's Edict No. 236 provided a substantial penalty for a freeman who is 'proved' to have destroyed an old boundary marker will be fined eighty soladi, with one half to the king and the other half to the property owner. $^{121}$ Markings on trees were apparently also employed as boundary markers, and a freeman cutting down such designated trees would likewise be fined eighty soladi, with half going to the king and half to the landowner. Should a slave cut down such trees at the instigation of

\footnotetext{
${ }^{117}$ Rothair's Edict No. 354.

118 Rothair's Edict No. 355. A like section, with the same required composition, addresses the reaping of another's meadow. Rothair's Edict No. 356.

${ }^{119}$ Laws of King Liutprand 46.XVII.

${ }^{120}$ Laws of King Liutprand 47.XVIII.

121 Should the actor be a slave, he might be killed unless he is 'redeemed' for forty soladi. Rothair's Edict No. 237. It is apparent that the rarely employed penalty of death would be applicable only if the slave was acting of his own initiative, rather than at the order of his master, in which latter case the penalty would most probably be only one for money damages. See discussion below of Edict No. 238 and 239.
} 
his 'lord' (master), the lord would be liable for eighty soladi as composition, to be apportioned similarly. ${ }^{122}$

Since the earliest of times societal custom and law have discouraged unjust enrichment. The reasons are multiple, but a section of the Laws of King Liutprand addresses the specific issue of wrongful possession of another's property, and the reaping of rewards thereby. Section No. 90.VII describes a man who wrongfully possesses another's property, including houses, land, animals or servants. Upon this man's eviction from the premises, he is required to 'render back the time and the fruit of the labor' he has unlawfully gained.

\section{Intentional Arson}

Rothair's Edict No. 146 provided treble damages for one 'who deliberately and with evil intent burns another's house[.]' 'Restoration' would be made 'according to the value of the burned house and its contents as determined by men of good faith from the vicinity.' This provision is significant for at least three reasons. First, it distinguishes what today is meant by 'intent' in tort, i.e., where one knows of or subjectively desires the consequences of their action, from specific, or deliberate and evil, intent. Second, it reflects a super-compensatory or punitive role of a damage action where the wrong is intentional in this sense. And third it represents a departure from the then general rule that responsibility for an injurious occurrence will be assigned by exclusive reference to oath taking and oath takers as to the probity of the party. Instead, Edict No 146 describes a role for 'men of good faith in the community' in the valuation of the damaged property. ${ }^{123}$

\section{Injuries or Damage Caused by Animals}

\footnotetext{
${ }^{122}$ Rothair's Edict No. 238. If the slave were to do so 'on his own authority', he could be killed unless 'redeemed' for forty soladi. Edict No. 239. As might be expected, 'justice' for transgressing slaves was generally harsh. E.g., marking a tree in another's wood, unless ordered by his master; penalty: loss of a hand. Edict No. 241.

${ }^{123}$ Rothair's Edict No. 149 provides similarly for the man who 'deliberately and with evil intent' burns a mill, who is required to 'pay as composition a sum equal to three times the value of the property and its contents'.
} 
Several provisions of Rothair's Edict pertain to injuries caused by dogs. No liability would attach if one's 'dog or horse or any other animal' were to go 'mad' and injure another person or his animals, nor would any penalty be imposed on one who killed such animal. ${ }^{124}$ If someone incited another's dogs to injure another man or his animals, the owner of the dogs would bear no responsibility, but instead the one who incited them. ${ }^{125}$ Absent madness or incitement, if a dog bites a man the owner is liable in composition. ${ }^{126}$ This last section is at a seeming variance with the dominant ' $d o g$ ' rules in modern western law, to whit, one is not responsible for the actions of their dog - presumably if properly confined or leashed - unless and until they have notice of its dangerous propensities.

The rules for damage or injuries caused by horses or beasts are different, as is true too in modern tort law. If a beast injures a man or another's animal, the owner must pay composition. ${ }^{127}$ Should a horse kick a man, or an ox injure him with its horns, or a pig with its tusks, the owner is responsible in composition for the killing or injury. ${ }^{128}$ That section concludes, as do several others similarly, with the admonition that upon payment of composition, "the feud, [and] the enmity, shall cease[.] ${ }^{129}$

A variation on monetary composition is found when one man's animal kills another's. Referencing the killing of an oxen, Edict No. 328 would requires that upon receiving the dead animal, the owner of the animal that caused the death must replace it with 'another animal of the same kind and value as the injured one was at the time it was hurt.' There are at least two significations of this Edict. First, it departs from composition in the form of money damages in favor of replacement. It is possible that this choice has to do with the role of oxen in agricultural society, i.e., more or

\footnotetext{
${ }^{124}$ Rothair's Edict No. 324.

${ }^{125}$ Rothair's Edict No. 322.

${ }^{126}$ Rothair's Edict No. 326.

${ }^{127}$ Rothair's Edict No. 325.

${ }^{128}$ Rothair's Edict No. 326. Compare Sandy v Bushey, 128 A 513 (Me. 1925)

${ }^{129} \mathrm{Ibid}$.
} 
less continuous work as a beast of burden. A man whose oxen was killed would be faced with the immediate and serious dilemma of replacing the animal. In such a case, a replacement animal would be a restitutionary remedy superior to the payment of money. Second, the requirement that the provision of the replacement oxen be the turning over of the dead oxen to the owner of the offending animal, can be seen as a confinement of the remedy to only what is necessary to put the owner of the dead oxen in the position he enjoyed before the wrong. A dead beast would have the residual value of its hide, its meat, its horns, etc., and in modernity, it might be considered unjust enrichment to permit the complainant to receive both a new oxen and also retain the dead one.

Edict No. 344 continues the theme of redress for injuries caused by animals, and again distinguishes between wrongful and innocent conduct by the owner. Several rules of this type can be visualized as arising from the acts of animal herders who either intentionally or carelessly let their animals enter the close of another. If the land is devoted to pasturage, the damage would be that caused by grazing. If the land is dedicated to crops, the result might be damage to the crops and also to any land as it might have been prepared for crops. Edict No. 433 provides that if one deliberately causes his horse or oxen to damage the property of another, he is responsible in composition for the damage caused and additionally fined one solidus. ${ }^{130}$ If the animal owner or herder swears that the harm was not intentional, he is relieved of the payment of one solidus, but must still pay composition for the damage done.

In some instances the treatment Rothair's Edict gives to damages caused by animals resembles an intricate minuet between the aggrieved party and the owner of the wandering animal. Edict No. 342 declares that if a landowner finds another's animal doing damage on his property, he is permitted to pen it up. If the owner of the animal does not come to claim it, the possessor may take the matter before a judge, or 'bring it before a

${ }^{130}$ The monetary equivalent of the damage caused is to be decided by an appraisal 'according to the custom of the place.' 
gathering in front of a church four or five times[,] ${ }^{, 131}$ a means of obtaining public notice that resembles later practices in medieval times of posting notices on the doors of a church. Once it has been 'made known to all by public proclamation that he has found the horse [or other animal,] . . . [i]f the owner of the horse does not come, "the finder is permitted to keep the horse. ${ }^{132}$ The Laws of King Liutprand No. 86.III refines parts of Edict No. 342 by stating that the man who finds another's horse doing damage to his property is only to be permitted to keep it penned up until a resolution of ownership can be had. If instead, the man "presumes to do to the horse anything more, ${ }^{133}$ the man so doing will be liable for composition in the measure of half the value of the horse.' By the indeterminate 'anything more', the law probably means exploiting the animal by riding it or putting it to any other service, rather than actually injuring the animal. It is to be expected that, in addition to composition, the horse be returned to its rightful owner unharmed.

Similar themes are discernible in Rothair's Edict No. 346. According to that section, if a man discovers another's animal causing harm to his land, he may bring an action in composition, and the owner of the animal must pay composition for the damage plus one solidus. If the animal's owner requests the return of the animal before this remedy is executed, the holder of the animal may request 'three soliquae as a pledge for the ultimate redemption' of the amount owed. There is an apparent presumption that in the orderly course of events, the complainant should accept the pledge, and if he does not and instead keeps the animal for more than one night, he will owe its owner one solidus. What if the original owner simply declines to reclaim the animal? Here the Edict takes an inexplicable course of countenancing punishment of the animal as a proxy for penalizing the wrongdoer. In what a modern psychologist

${ }^{131}$ Rothair's Edict No. 342. Presumably 'it' refers not to the animal but rather to the issue.

${ }^{132}$ If the animal later dies, the new owner must keep the hide to show it if the original owner arrives eventually If the new possessor fails to do this, he must return a horse 'ninefold.[.]' Id.

${ }^{133}$ By the indeterminate 'anything more' is probably meant, on one end of the spectrum, injuring the animal, or on the more likely end, exploiting the animal by riding or other service. 
might today term a displacement reaction, the possessor is permitted to keep the animal for nine nights and give it only water, and 'if anything is killed by that animal it shall be imputed to the negligence of him who neglected to disengage his pledge.'

\section{Human Injuries to Animals}

Rothair's Edict includes sections on human depredations upon or injuries to animals. The lesser among these, such as the penalty exacted when a man 'cuts off the tail of another man's horse to the very bristle,' provide for payment of as little as six soladi, ${ }^{134}$ a provision practically indistinguishable from that regarding molestation of a horse by cutting its tail found in the Burgundian Code. ${ }^{135}$

\section{Trespass to Chattels}

As is true today, the wrong of trespass to chattels was considered a lesser offence than conversion. ${ }^{136}$ If a man were to meddle with another's property, knowing that the property was that of another, he would be fined minimally, at least insofar as such a fine might be compared with the penalties for other delicts. ${ }^{137}$

\section{Theft or Conversion}

Regarding theft in an amount greater than ten silequae, a freeman, if caught in the act (fegangi), was required to 'return that stolen ninefold' and further to "pay eighty soladi compositon for such guilt[.]" ${ }^{138}$ Thieves not discovered in the act but rather through an informant (proditor)

\footnotetext{
${ }^{134}$ Rothair's Edict No. 338.

${ }^{135}$ See note 93 and accompanying text.

${ }^{136}$ See above notes 55-58 and accompanying text

${ }^{137}$ E.g., Rothair's Edict No. 342, declaring that if, 'after [a man] has announced that [a horse] is not his own, he mounts it, he shall pay two soladi' as composition.

${ }^{138}$ Rothair's Edict No. 253. If the thief was unable to make such composition, "he shall lose his life[,]" although there is no reliable indication of how frequently this alternative penalty was imposed.
} 
received a lesser punishment of simple restoration. ${ }^{139}$ The graded elevation of penalties as tied to the value of the property stolen parallels today's distinctions between misdemeanor theft and felony theft.

Edict No. 281 provided that theft of wood from another's woods would result in the exaction of six soladi from the owner. The logic behind the law is revealed by the lack of a restoration remedy; because the wrongful taking is of wood, by the time the wrong is discovered and an action is brought, the property in question might already have been consumed as fuel or used as timber.

By the time of the Laws of King Liutprand, thievery was apparently thought of as sufficiently pernicious as to warrant imprisonment. Judges were instructed to 'make a prison underground' in their respective districts. Thieves would be required to pay composition for the value of the theft, and in addition, they could be placed in prison for two to three years. The doubly unfortunate thief who did not have the resources to pay composition could be handed over to the victim, and the victim was permitted to "do with [the thief] as he pleases. ${ }^{140}$ Recidivists could be shaved (decalvit), beaten or branded on the forehead and face. A repeat offender could be sold 'outside the province,' which is to say, sold into servitude. $^{141}$

An asportation of another's animal due to an innocent mistake is to be distinguished from purposeful theft. If a man 'takes someone else's horse or other animal believing it to be his own,' and was accused by the owner of wrongdoing, the respondent was permitted to 'offer an oath that he did not take it with evil intent or with the purpose of causing contention, but because he believed it to be his own.' Upon returning the animal unharmed, he could be absolved of any claim of theft. If, on the other

\footnotetext{
${ }^{139}$ Rothair's Edict No. 255.

${ }^{140}$ Laws of King Liutprand 80.XI.

${ }^{141} \mathrm{Ibid}$. As to this lattermost remedy, the provision suggests that a higher burden of proof should be required, stating that selling a man should be 'a proved case for the judge ought not to sell the man without certain proof.' This concluding language is probably best interpreted as meaning 'proof to a certainty', as would befit a penal sanction of this order.
} 
hand, he is not prepared to so swear, it would be interpreted as an admission of wrongdoing, and he would be liable to "return the horse eightfold. ${ }^{142}$

\section{Maintenance of Dangerous Instrumentality}

If a man constructed a fence and left the head of a pole extend above the rest of the fence, and should a man be injured or die after impaling himself on that pole, he would be required to pay composition. ${ }^{143}$ Here, presumably, the composition for death would be in the amount of wergild, while the composition for injury short of death would be determined with reference to the severity of the injury.

\section{Responsibility for the Insane}

Edict No. 323 provides: 'If a man, because of his weighty sins, goes mad or becomes possessed, nothing shall be required from his heirs.' This rule represents a treatment of responsibility for the wrongs of the mentally infirm that departs from the modern standard holding that an insane person (more likely his guardians or insurers) can be liable for his torts. ${ }^{144}$

\section{Deceit, Fraud and Perjury}

All customary law and early law codes contained provisions regarding deceit or false witness, thought not all dealt with perjury. The Laws of King Liutprand did so, and provides that if any freeman advises another freeman to perjure himself[,]' he is liable to pay 100 soladi 'for that illegal advice which he offered contrary to reason. ${ }^{145}$

Rothair's Edict No. 192 treated an issue that seems unlikely today, but would have been more plausible in days when young and marriageable women were unemancipated. A 'girl' could be betrothed to another

${ }^{142}$ Rothair's Edict No. 342

${ }^{143}$ Rothair's Edict No. 303.

${ }^{144}$ E.g., McGuire v. Almy, 8 N.E.2d 760 (Mass 1937)

${ }^{145}$ Laws of King Liutprand 72.III. 
through the actions of her father, a brother, or by other relatives. Any family member who participated in the betrothal, and who later 'for some strange reason' entered into 'a secret agreement' that the girl be betrothed to another, or who consented to another man's 'taking the woman to wife forcefully even with her consent, would be bound to pay the original putative husband 'double the marriage portion which was agreed to on the day of the betrothal.' 'Afterwards,' Edict No. 192 concluded, 'the [originally] betrothed man may not seek more from the prosecution of them or their sureties.'

This provision is notable in more than one respect. First and most obviously, it enunciates the subordinate, even chattel-like status of women in that era. Second, it seemingly provides a remedy for fraudulent deprivation of prospective advantage. And third, by describing a monetary limitation on the defrauded suitor at 'double the marriage portion [dowry]', and precluding any further attempt to exact more, it is an early example of liquidated damages.

\section{Dignitary Wrongs}

Since time immemorial, it has been recognized that defamation, in addition to being a wrong, carries with it a substantial risk of physical retaliation. Edict No. 381 provides in effect a safety valve for the avoidance of the escalation of potentially injurious enmity, and states: 'If anyone in anger calls another man a coward' he may absolve himself of blame, and simultaneously reduce the sting of the insult, by taking an oath that he spoke in anger and does not know the other man in fact to be a coward. He would be nevertheless obligated to pay twelve soladi in composition. Should the man 'persevere' in the inflammatory comment, 'he must prove it by combat, if he can[.]'

${ }^{146}$ Id. The provision concludes, incongruously, by stating that the man persevering in the claim may, as an alternative to trial by combat, pay twelve soladi as composition. This last language cannot be readily reconciled with the proposition that the twelve soladi in composition was attendant upon swearing that the man uttered the charge in anger and did not know of its bona fides, i.e., the original provision for composition is in the context of the man backing down from the claim, and permitting both men to save face. It seemingly makes no sense that where the man does retract the claim, and indeed 
From the time of the Lombards up to the years leading to 1000 A.D., the kingdom that comprised much of modern Italy saw a succession of Carolingian rulers. One of the most notable was Louis II (844-75). He was the last king to truly rule the realm. From 875-962, autonomy migrated increasingly from the kings to the localities, such that by the opening of the new millennium, popular dismissal of central authority signified an Italian state that could no longer claim that mantle. ${ }^{147}$

\section{The Laws OF THE Salian Franks}

\section{A. Frankish Law, Generally}

By the early Fifth Century, the Burgundians, the Visigoths, and the Franks had settled in Gaul, in agricultural communities. The Franks comprised two primary populations: the Salians and the Rippuarians. Their laws were named respectively the Pactus legis Salicae and the Lex Ripuaria. The Salian law reflected no real attempt at organization or systemization, even though it was rendered in Latin. Attributed often to the work of Clovis (476-496 A.D.) ${ }^{148}$, who brought Christianity to his people, the Pactus legis Salicae showed little Roman influence and no

continues to traffic in it, that the Edict provision directs the disputants in the direction of trial by combat or the payment of the same amount in composition. Put another way, if the provision is read literally, the verbal aggressor is permitted resolve the matter with the payment of damages without having taken any steps to calm the situation.

${ }^{147}$ Historian Chris Wickham writes:

By the late tenth century, being a count was no longer very different from being an ordinary landowner; the state bureaucracy was dissolving; the concerns of the ecclesiastical and lay aristocracies were directed towards their own power bases, and barely towards the state at all . . . In 1024, the inhabitants to Parvia revolted and burned down the royal $\mathrm{p}$ palace there; after that, Italy barely existed as a state.

Wickham (n 8) at 168.

148 Gibbbon's (n 14) 523. 
Christian influence at all. It was more or less a recitation of Salian Frank customary law. ${ }^{149}$

Among both Frankish tribes, the king's original duties were the protection of the real and the keeping of the domestic peace. With regard to the latter, which we have encountered above, feuds were discouraged by means of a feud fine, called a feudus, which would be imposed with two third devolving to the realm and one third to the magistrate who decided the matter. If the laws proved inadequate to the king's purposes, he could issue an edict (bannum) that operated as today's injunction, and the failure to do or cease to do what the crown ordered would result in a fairly steep fine of sixty soladi. ${ }^{150}$ The Franks followed the pattern of the other German tribes in the perpetuation of blood feud as one means of resolving a slaying. At the same time they also adopted the more progressive option of the payment of wergeld, as has been defined earlier. Acceptance of the offered wergeld by the victim's kinship group would resolve the feud. As might be imagined, some greater inducement for the victim's family to not respond violently might be needed, and this would only come in the Eighth Century. ${ }^{151}$

Had the Frankish hegemony lasted long enough, it is possible conceptually that there would have developed a unitary pan-European

149 The Lex Ripuaria, in contrast, revealed many similarities with the earlier Burgundian Code. A recitation of some of the Frankish laws, those comprising the Lex Ribuaria, and their Burgundian Code counterparts, was prepared by historian Theodore John Rivers: Lex Ribuaria 48 (46) par 1, 2 (an animal killing another man or another animal; Lex Burgunsdia Sec. 18 par. 1) Lex Ripuaria 49 (47) sect. 1, 2 (following the trail of a stolen animal; Lex Burgundia Sect. 16 p. 1-8); Lex Ripuari Sect. 68 (65) par. 3 (declining to offer hospitality; Lex Burgundia Sect 38); and Lex Ripuaria Sect. 91 (88) Sect. 1 (court officials taking bribes; Lex Burgundia preface, cap. 5). Laws of the Salian and Ripuarian Franks 9 (Theodore John Rivers, transl.) (AMS 1986). Professor Rivers continues by commenting that many other similarities could be catalogued, but the reliability might tail off due to uncertainty as to whether the Lex Burgundia and the Lex Ripuaria were themselves influenced by yet a third source or sources. Ibid. 9-10.

${ }^{150}$ A definition of a solidus and of multiple soladi can be found at note 42 above and accompanying text.

${ }^{151}$ Laws of the Salian and Ripuarian Franks 13, 14 (Theodore John Rivers, transl.) (AMS 1986). 
body of law. This was not be the case, however, and the European collectivity would pass several centuries with no central lawmaking and with such law as was developed governed by municipal or regional law, which reflected most closely a region's customary law.

Putting aside Visigothic law ${ }^{152}$ for the purposes of this article, I will discuss the law of the Franks, and the Salian Franks in particular.

\section{B. The Salic Laws of the Salian Franks}

We turn now specifically to Salic law, as found in the Pactus Legis Salicae. ${ }^{153}$ We will see it to be, as we have seen the other Gothic codes, a work of substantial organizational achievement.

\section{Theft and Conversion}

The Pactus Legis Salicae opens with six provisions concerning, in the main, farm animals: the theft of pigs, cattle, sheep, goats, dogs, together with birds and bees. ${ }^{154}$ The penalty for the theft of a pig varied upon the circumstances. Should it be an unweaned piglet from the 'first enclosure' (the perimeter enclosure) or the middle one, the composition would be three soladi. If the piglet was stolen from the third enclosure, i.e., the most protected enclosure, the composition would be fifteen soladi, plus additional composition in the amount of the piglet's value and a fine for loss of use. Lastly, the theft of a piglet from a locked pigsty would be liable in composition for forty-five soladi. It is evident that the level of

${ }^{152}$ See generally P.D. King, Law and Society in the Visigothic Kingdom (Cambridge 1972).

${ }^{153}$ The references to follow are from the translated Salic and Ripuarian laws as found in Laws of the Salian and Ripuarian Franks (Theodore John Rivers, trans.) (AMS 1986). In the pursuit of brevity, I will from this point forward employ only references to the sections of the laws themselves.

${ }^{154}$ Pactus legis Salicae Sect. 2 par. 1-3. As to other related offenses, for example, stealing and injuring a sow with such severity so that she cannot give milk would be required to make composition of seven soladi, plus a payment in the amount of the value of the sow, 'and a fine for the loss of its use.' Ibid. para 5. 
liability increased on the basis of two factors: (1) the thief's industry, i.e., his culpability; and (2) the level of the intrusion or penetration onto the owner's property. The provisions continue with great particularity to describe the offenses and the penalties therefore, leaving nary a doubt as to the centrality of pig-raising to the Salic agricultural community.

For the theft of cows, increasing penalties, from three to thirty-five soladi, would be imposed, depending upon whether the animal was an unweaned calf, a one-year old, a two-year old, a cow without a calf, or a cow with a calf. For theft of an ox, the penalty might range from thirty five to forty five soladi, the latter liability being imposed if the ox was 'a bull that leads the herd.' 155

A similar hierarchical approach was taken for the theft of sheep. For the theft of an unweaned lamb, the penalty was less than one half a soladus, as measured in denarii, in addition to its value and a fine for the loss of its use. ${ }^{156}$ Theft of a one or a two-year old sheep would bring a requirement in compositon of three soladi, with the highest level of penalty imposed for theft of 'forty, fifty, sixty or more' adult sheep, for which the penalty would be sixty-two and one half soladi. ${ }^{157}$ A similar set of rules, differing only in the description of the animal, was taken regarding theft of goats, dogs, birds, and bees. ${ }^{158}$

Comparable provision is made for, and different designated amounts in composition are assigned to, a wide variety of other thefts, ranging from theft from another's garden to graft from a fruit-bearing tree. Other specified thefts include the taking of flax from another's field, the mowing of another's meadow, ${ }^{159}$ the grazing of one's animals on the land

\footnotetext{
${ }^{155}$ Pactus legis Salicae s 3 paras 7,8.

156 Throughout the Pactus legis Salicae provisions, in addition to setting fixed monetary composition in soladi the paragraphs add language to this effect: "in addition to its value and a fine for the loss of use.' Unless otherwise noted, for brevity the reader may assume the inclusion of such extra penalties.

${ }^{157}$ Pactus legis Salicae s 4 paras 1-5.

${ }^{158}$ Pactus legis Salicae ss 5,6,7,8.

159 Technically trespass, but also theft of the opportunity of the rightful owner to profitably exploit his land.
} 
of another, the plowing of another's field without sowing it, the plowing and sowing another's field, the harvesting of another's grapes, the cutting of another's lumber, the stealing of another's firewood, and the taking of another's eel net. Theft of services is also an extensively detailed subcategory of offence, specifically theft of the services of another's slave. The special offense of the theft of a woman's bracelet shows, perhaps, that the Franks were not one-dimensional utilitarians after all. ${ }^{160}$

When the theft was done by a freeman, the liability was both compensatory and quasi-criminal. The theft of something with a value of two denarii would be responsible for 600 denarii (or fifteen soladi). Sterner penalties were imposed when the thief broke into the house by breaking a lock or using a skeleton key, in which event his liability would be forty-five soladi. ${ }^{161}$

Depriving a man of his horse was a matter of special gravity. Even the simple mounting and riding of another's horse, irrespective of intent to steal, could carry with it liability of thirty soladi. ${ }^{162}$ Separate attention was devoted to theft of boats and of theft committed in a mill. As to boats, taking another's boat and crossing the river with it imported a penalty of three soladi. If the boat owner can prove, however, that the man actually intended to steal the boat, the penalty would be fifteen soladi. More serious still would be the composition required of the man who broke in to steal a vessel 'that is locked up' and an even greater penalty would accompany proof that the man stole a boat was both locked up and suspended within a shelter. ${ }^{163}$

Regarding mills, if a freeman stole grain from another's mill, he would be liable in the amount of fifteen soladi in addition to its value and a fine for the loss of its use.' The thief who took an iron tool from that mill

\footnotetext{
${ }^{160}$ Pactus legis Salicae s 27 paras 6, 7, 8, 13, 17, 19, 23, 24, 25, 27, 28,34 .

161 Pactus legis Salicae s 11 para 5.

162 Pactus legis Salicae s 23 para 1.

${ }^{163}$ Pactus legis Salicae s 21 para 1 (three soladi); para 2 (fifteen soladi); para 3 (thirty five soladi; and para 4 (forty five soladi).
} 
would incur a penalty of forty-five soladi. One who 'breaks a sluice in another man's water mill' would be held liable for the same amount. ${ }^{164}$

The centrality of barnyard animals to the Frankish economic welfare led logically to special treatment for their theft. For the theft of the bell of a herd of pigs, the penalty was fifteen soladi; for the theft of the bell of a cow, three soladi; for the bell from a horse, fifteen soladi; and for the hobble of a horse, three soladi. ${ }^{165}$

\section{Breaking and Entering}

The laws of the Salian Franks identify a variation of wrongs for which intruders may be found liable, with distinct amounts in composition liability assigned to each. They range from tearing down another's enclosure; ${ }^{166}$ to breaking into an unlocked workshop; ${ }^{167}$ to breaking into a locked workshop; ${ }^{168}$

\section{Harm Caused by Animals}

The liability provisions regarding crop damage caused by barn animals seem less concerned with composition than with (1) the penalties that attached to false denials; and (2) the protection of the animals from harm at the hands of the landowner. Regarding first the penalties for false denials, we turn to Pactus legis Salicae Section 9, Paragraphs 1, 4, 7, and 8. Each of these sections relate to injury to an animal that has trespassed upon another's land and set a fine for any landowner who injures the animal of another that has come under his control. The provisions also

\footnotetext{
${ }^{164}$ Pactus legis Salicae s 22 paras 1, 2,3.

${ }^{165}$ Pactus legis Salicae s 27 paras 1 (pigs), 2 (cow), 3 (horse bell); 4 (horse hobble). For the bell to a herd of pigs and also the horse hobble the paragraphs also include penalties for 'its value and a fine for the loss of its use'. It is probable that such additional penalties originally accompanied each animal and each type of theft.

${ }^{166}$ Pactus legis Salicae s 27 para 22 (fifteen soladi).

${ }^{167}$ Pactus legis Salicae s 27 para 29 (fifteen soladi).

${ }^{168}$ Pactus legis Salicae s 27 para 30 (forty-five soladi, plus 'in addition to the value of what is stolen' and 'a fine for the loss of its use.'). Should the burglar steal nothing, he would still be liable for fifteen soladi.
} 
condemn and punish specifically anyone who, with another's animals in his possession, injures it.

\section{Theft by Force}

In matters of punishment for ambush and robbery, the Pactus legis Salicae favored the Salian Franks over the Romans. Any man robbing a freeman would be liable in sixty-two and one half soladi. If a Roman robbed a Salian Frank, and the proof was not definite, the Roman could try to absolve himself with twenty-five oathtakers. Should this number of oathtakers not be found, the accused had a choice between the abovenoted money penalty and 'the ordeal of boiling water." 169 If, on the other hand, the Frank should rob the Roman, and there was no definite proof, the accused could summon twenty oathtakers. Absent this number, he could discharge his liability with the payment of thirty soladi. Noticeably absent was the boiling water alternative.

Arson

Several Sections of the Pactus legis Salicae carefully parsed the types of arson and the appropriate penalty for each. For the very serious wrong of setting fire to another's house in which others were known to be sleeping, he would be liable for 2500 denarii, or sixty-two and one half soladi. If a man were to perish in the blaze, the arsonist would be liable for sixty-two and one half soladi, plus a fixed wergeld of two hundred soladi, and if the house was destroyed, another sixty two and one half soladi. ${ }^{170}$

Composition in the same amount (2500 denarii) would be imposed for setting fire to an adjoining house made of wicker, a granary or a barn with stored grain, or a pigsty. Lesser liability would be imposed for setting fire to or cutting down another's fence or hedge. ${ }^{171}$

\footnotetext{
${ }^{169}$ Pactus legis Salicae s 14 paras 1, 2. The ordeal of boiling water entailed having the accused place his hand in boiling water. If within a time certain after doing so his hand was uninjured, he was considered innocent, etc.

${ }^{170}$ Pactus legis Salicae s 16 para 1.

${ }^{171}$ Pactus legis Salicae s paras 2, 3, 4, 6, 7.
} 
Assault and Battery

The particularity of the Pactus legis Salicae regarding battery and wounds thereby caused might lead us to think that they had imagined and written corresponding rules for every corporeal wrong one man can inflict on another, and we would not be far off.

One seeking but failing to kill a man with a blow would be liable for 2500 denarii, or sixty-two and one half soladi. An endeavor to kill a man with a poisoned arrow, which missed, would result in the same monetary penalty. ${ }^{172}$ If the wrongdoer wounded a man so that 'blood spurts on the ground', the penalty was fifteen soladi. One inflicting a head wound 'so that the brain appears: would be liable in a like amount. ${ }^{173}$

A head wound sufficiently serious as to cause "the three bones that cover the brain [to] protrude' would incur liability of thirty soladi, as would a wound that 'is between the ribs and ... penetrates as deep as the intestines.' If the latter wound failed to heal and continued to bleed, an additional liability of 2500 dinarii would be imposed, plus nine soladi for medical treatment. ${ }^{174}$ Other provisions draw distinctions between striking with a stick and either causing or failing to cause blood to flow, and striking 'another three times with a clenched fist' irrespective of injury. ${ }^{175}$

Other specific wounds were addressed with a specificity one might encounter in a schedule of modern workers' compensation laws. An incomplete but representative selection of the injuries and the composition associated therewith might include: mutilation of another's hand or foot, the knocking out of an eye, or cutting off an ear or a nose,

\footnotetext{
${ }^{172}$ Pactus legis Salicae s 17 para 1. For computations to follow, if the penalty in dinarii does not equal a whole number, I will use only the amount of dinarii.

${ }^{173}$ Pactus legis Salicae s 17 paras 3, 4.

${ }_{174}^{174}$ Pactus legis Salicae s 17 paras 6,7.

${ }^{175}$ Pactus legis Salicae s 17 paras 8, 9, 10.
} 
100 soladi; ${ }^{176}$ cutting of another's hand so that it 'dangles maimed' or cutting it altogether through, or cutting off another's thumb or foot, 2500 denarii; cutting off another's thumb that it 'dangles maimed', thirty soladi; cutting off the second finger, 'with which one shots an arrow', thirty-five soladi; cutting off two fingers, thirty-five soladi (if three fingers, forty-five soladi); knocking out another's eye 2500 dinarii; cutting out another's tongue 'so that he cannot speak', 100 soladi; breaking another's tooth, fifteen soladi, castrating a freeman, 100 soladi, and 200 soladi if the entire genitalia. ${ }^{177}$

\section{Public Nuisance}

A cluster of the provisions of the Pactus legis Salicae address the classic public nuisance scenario of the unprivileged blocking of a public way. The blocking or driving away of a 'freeman from his way' would be liable for fifteen soladi, and to do so to a freewoman or girl would be penalized by a fine of forty-five soladi. The barricading of a road that goes to water, fifteen soladi.

As to the steeper liability imposed for blocking or impeding a freewoman or a girl, when compared to the penalty for the same offence against a man, it is possible to imagine whimsically that this shows some germinal stage of chivalry in the Frankish culture. It is more probable that chivalry aside, women and children turned away from the public road and forced in some instances to travel less public paths were, as compared with men, put a greater risk of violence.

\section{False Accusation and Defamation}

\footnotetext{
${ }^{176}$ Pactus legis Salicae s 29 paras 1.

177 Pactus legis Salicae s 29 paras 2, 3, 4, 5, 6, 7, 8, 10, 12, 15, 16, 17, 18. Other paragraphs within the same section, specifically paras $1,1,13$, and 14 , designate other monetary damages, for nose, ear, and foot injuries, but the differences are only in degree. They most likely reflect amendments or revisions to the Pactus legis Salicae that were layered in over time without the corresponding redactions of the earlier versions. See also Pactus legis Salicae s 29 para 1.
} 
If a man accused before the king an innocent man who was not thereby able to counter the claim, the accuser would be liable for 2500 dinarii. ${ }^{178}$

One who hurled insults of several different types might find himself liable. For calling another a louse, the penalty was fifteen soladi; a skunk, three soladi; a freewoman a prostitute, forty-five soladi; a fox or a hare, three soladi. ${ }^{179}$

These initial examples prompt some observations. First, the identification of certain statements as being per se defamatory bears a close resemblance to the common law's later segregation of certain slurs, such as impugning unchastity, as slander per se. Also, regarding calling a man or a woman yet another living thing would not today be defamatory, as its impossibility of truth would be evident to any observer. For this reason, it may be that the primary objective of the liability rule was to prohibit what today are called 'fighting words', which, notwithstanding the First Amendment, a state can permissibly forbid, in order to interdict breaches of the peace.

Also of interest, the consequence of calling another a louse was a fine greater than that for any other animal, which might be explained that of the several animals, having lice is an extremely communicable condition that puts all associating with the target of the insult at risk of contracting it, and, it follows, unfair ostracism if the accusation is not true. Lastly, a remedy for being called a prostitute was only available to a freewoman, a reiteration of the rule that slaves owned nothing, not even the right to their reputation.

Finally, a freeman who imputed that another had 'thrown away his shield and ... taken to flight', and who was unable to prove this, would be liable in the amount of three soladi. And one unable to prove the truth of an accusation that another was an informer or a liar would be required to pay fifteen soladi. ${ }^{180}$

${ }^{178}$ Pactus legis Salicae $\mathrm{s} 18$ para 1.

${ }_{179}^{179}$ Pactus legis Salicae s 30 paras 1, 2, 3, 4, 5 .

${ }^{180}$ Pactus legis Salicae s 30 paras 6,7. 


\section{CONCLUSION}

As summarized by Prof. Edward Peters, 'the study of the Germanic law codes has much to contribute to the comparative history of law and society. ${ }^{, 181}$ The author's hope is that this presentation has succeeded in some small way to that goal.

Beyond this, I advance two thoughts. The firsts pertains to the relative significance of Justinian's work in the time following its promulgation and imposition. The second relates to the importance of the Gothic peoples, here most specifically the Burgundians, the Lombards and the Salian Franks, advancements in legal and societal advancement upon achieving control over most of the former Western Empire.

As to the enduring significance of Justinian's work, it has never been disputed that the form, the substance, and the multiple adumbrations of Justinian's Code and the Corpus Juris Civilis are, taken together, a highly accurate representation of Roman customary law and legislative enactment at the time of their mid-Sixth Century promulgation. The question remains this: what were the reach and the depth of the influence of this work in the centuries that followed first the fall of the Western Empire, and later that of the Byzantine Empire. I suggest here that, to scholars and observers from the early Middle Ages through approximately 1000 A.D., Justinian's contribution has always been larger than life. Put another way, it was only through hybridization with Gothic law that Roman law would attain a substantial measure of its enduring influence on European law.

The Corpus Juris Civilis was only promulgated during Justinian's shortlived (seventeen year) re-consolidation of the Western Empire with that of the East. Almost immediately on the heels of this, the western territories were governed by

their new Germanic invaders. In none of these territories was Roman law banned, it is true. Rather, in each, the customary law of the usurpers would hold the edge, countenancing Roman law but not advancing it.

${ }^{181}$ Edward Peters, Introduction, The Lombard Laws (n 6) xix. 
Indeed, even if Burgundians, the Lombards and the Salian Franks had rulers who intended to continue a particularized application of Roman law, it would have been extremely difficult to do so. After the fall of the Western Empire, large parts of the Corpus Juris Civilis were simply unavailable, and would not reappear until the time of the Crusades.

It is true that upon the discovery of a sufficient part of the original texts Roman law would thereafter become an important theme in the studies in Bologna and elsewhere. By this time, however, centuries had passed, in which Roman law had already been ineradicably altered by contact with the customary law of Germanic populations.

Upon the fall of Justinian, the Romans themselves would not be the conquerors of any of the several Gothic groups. ${ }^{182}$ However, it was the coming to Christianity of these peoples and the inexorable reconfiguration during the later Middle Ages of the kingships into nations that came to resemble modern Europe, and the reintroduction of RomanHellenic structure to the praxis of such states, that commended to observers description of the Goths, at least prior to their conversion, as barbarians. And yet as has been described, in Italy and elsewhere, many Germanic contributions to the law can be correctly called progressive.

What were the principal contributions of the Gothic codes? We must look beyond some scholarly critiques that would characterize the Germanic adumbration of new law codes based reflecting both their own customary law and also Roman law as a simple aping of the Roman model. ${ }^{183}$ This assessment is misleading, because the Germans came about their published codes by a far more textured means. For many, the codes were preceded by decades in which the tribes either occupied land upon the perimeter of the Western Empire, taking on the obligation of

\footnotetext{
${ }^{182}$ Nor, for that matter, would there be any Roman resurgence in Britain over the Celtic, Saxon, or Scandinavian groups.

${ }^{183}$ Esther Cohen, The Crossroads of Justice: Law and Culture in Late Medieval France 16 (E.L. Brill 1993): "the greatest influence of Roman law lay in the act of codification, which provided the impulse for Germanic leaders to ape the emperor in writing down the laws of their people.'
} 
defending the Empire against more dangerous threats. In the course of this symbiotic relationship, the Germanics of necessity had commercial and cultural intercourse with Romans and their laws. By another means described above, that of the extension of hospitality, Germans in Gaul, modern Italy and elsewhere actually partnered with Romans, further stirring the potlatch that would become the law codes. The codes themselves represented freestanding recitations of the law that would govern a multicultural people comprised of Romans and Germanics. Their original content and further by their constant revision represented new law for newly organized political states. That the Franks, the Burgundians and the Lombards adopted written presentations, most often in Latin, with an organization, with which the Romans had enjoyed success, was simply astute and does not by any stretch make their contributions derivative.

The Goths were largely successful in turning their culture away from its kinship origins of violent justice to systems of composition for injury. They developed subtle economic incentives to put away feud and adopt economic compensation or compensation in kind. The adoption of wergeld and also the widespread use of codified tables of composition to be associated with particularized wrongs, in addition to presaging in some way modern workers compensation, sent an understandable message of deterrence to those who might turn to mayhem to solve disputes. Apart from feud, many ancient Germanic practices, such as trial by boiling water, were tamed or eliminated in the pursuit of new agricultural societies. The codes adopted distinctions between accidental and intentional harm, as well as evaluations for negligence liability employing approaches uncannily similar to modern standards of duty and proximate cause. The list could go on.

When the legal and social history of the period is read in its entirety, it becomes clear that the Goths neither destroyed Roman law, nor were they its caretakers. Instead, they created an entirely new society, adapted to their new needs. They rejected any old practices, be they Roman or Gothic, which did not advance their new societies. They developed and codified new law and a new social order the progressiveness of which, 
when seen relative to its time, stood on an equivalence with any other population of the early Middle Ages. 